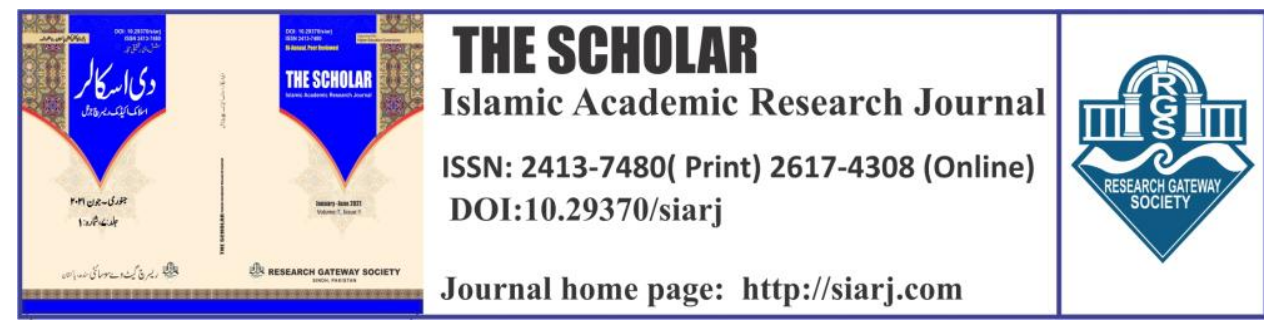

$$
\begin{aligned}
& \text { تخ تمتجاتس كبياركاصولوضوابط }
\end{aligned}
$$

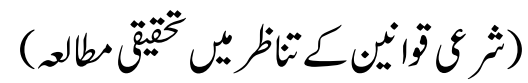

\title{
BASIC RULES AND REGULATIONS PROHIBITING TRADE (RESEARCH STUDY IN THE CONTEXT OF SHARIA LAW)
}

\section{Shahzada Imran Ayub}

Assistant Professor, Dept of Islamic Studies,

The University of Lahore, Lahore.

Email: Imran.ayub@ais.uol.edu.pk

ORCID ID:

https://orcid.org/0000-0001-6201-1993

\section{Irfan Jafar}

Lecturer, Dept of Islamic Studies, The

University of Lahore, Lahore.

Email: muhammad.irfan@ais.uol.edu.pk ORCID ID:

\section{https://orcid.org/0000-0003-3019-6545}

To cite this article:

Ayub, Shahzada Imran, and Irfan Jafar. "BASIC RULES AND REGULATIONS PROHIBITING TRADE (RESEARCH STUDY IN THE CONTEXT OF SHARIA LAW)." The Scholar-Islamic Academic Research Journal 7, No. 1 (June 30, 2021): 127-145.

To link to this article: https://doi.org/10.29370/siarj/issue12urduar7

\begin{tabular}{|c|c|}
\hline Journal & $\begin{array}{l}\text { The Scholar Islamic Academic Research Journal } \\
\text { Vol. 7, No. } 1 \text { || January -June } 2021 \text { || P. 127-145 } \\
\text { Research Gateway Society }\end{array}$ \\
\hline DOI: & $10.29370 /$ siarj/issue12urduar7 \\
\hline$\underline{\text { URL: }}$ & https://doi.org/10.29370/siarj/ issue12urduar7 \\
\hline License: & Copyright c 2017 NC-SA 4.0 \\
\hline Journal homepage & $\underline{\text { www.siarj.com }}$ \\
\hline Published online: & 30-062021- \\
\hline
\end{tabular}

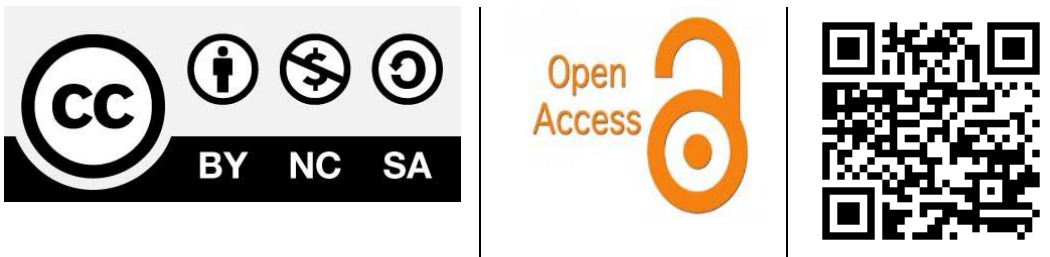




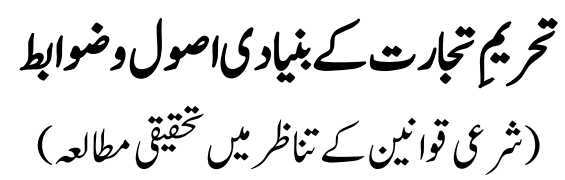

\title{
BASIC RULES AND REGULATIONS PROHIBITING TRADE
} (RESEARCH STUDY IN THE CONTEXT OF SHARIA LAW)

\author{
Shahzada Imran Ayub, Irfan Jafar
}

\section{ABSTRACT:}

Trade and commerce are an integral part of human life; therefore, it is important to know its Islämic principles and laws. Because in matters (business and transactions, etc.) the principle is that everything is halāl unless there is evidence of its prohibition. Therefore, if the rules that make a business fall into the category of hāraām are known, so halal sources of income can be easily adopted according to the Shariāh requirements. Considering the Shari'ah arguments and the sayings of the Islamic Scholars and Jurists, the result of the rules and regulations that prohibit any trade is that it is haraam to trade in anything that is forbidden by sharee'ah, it is haraam to trade in anything that is najis (impure) or hāraām, It is hāāraām to trade in anything that is a source of sin, any trade involving fraud, dissatisfaction of the parties, loss of seller or customer, unknown saleable item or unknown price is hāraām, trade is haraam in times or places where trade is forbidden such as after the call to prayer on Friday and buying and selling in mosques, etc. It is hāraām to trade in anything that is intoxicating and any trade that involves interest in any way is haraam.

KEYWORDS: Trade, Ḥāraām ,Principle, Islāmic Principles And Laws, Source Of Incom 


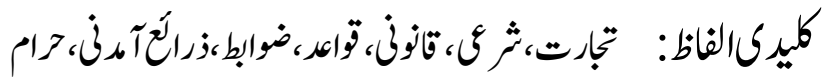

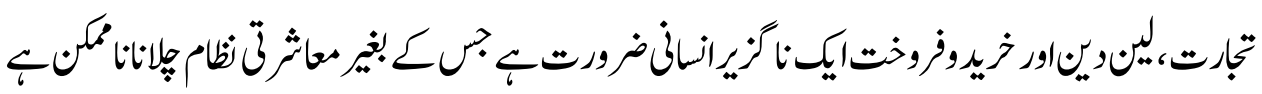

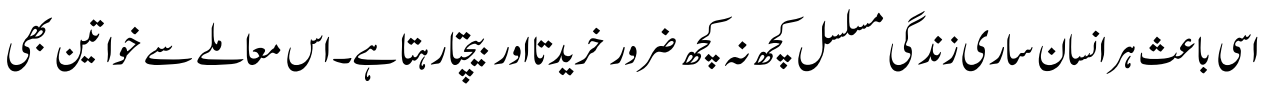

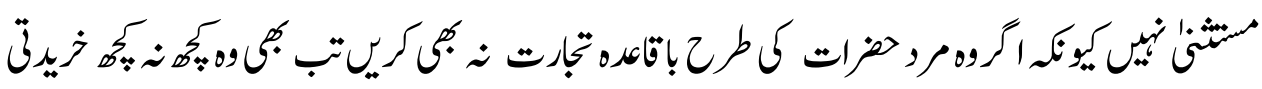

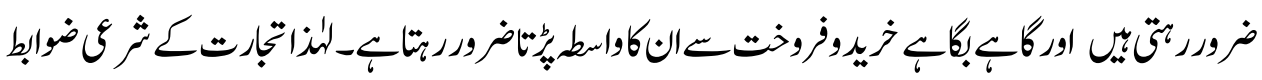

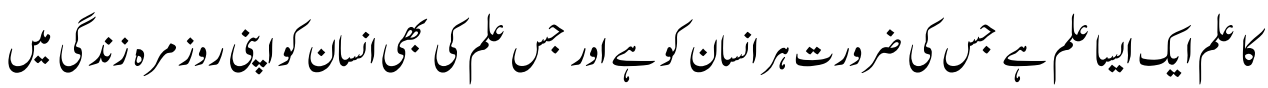

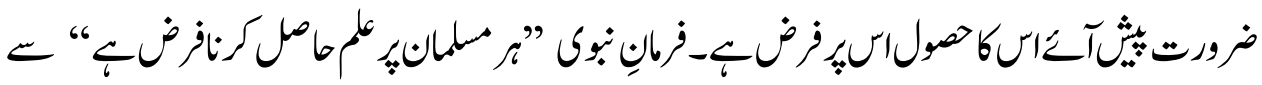

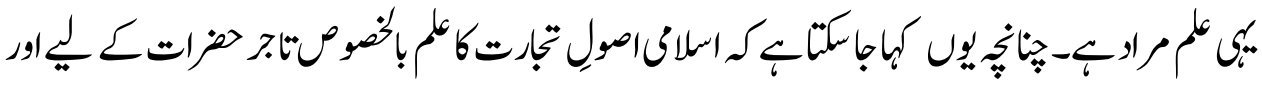

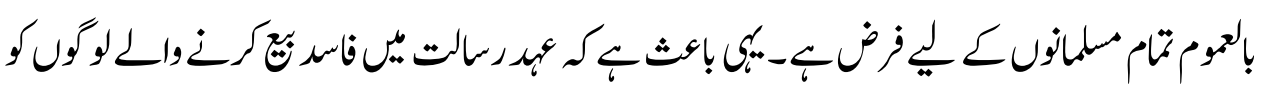

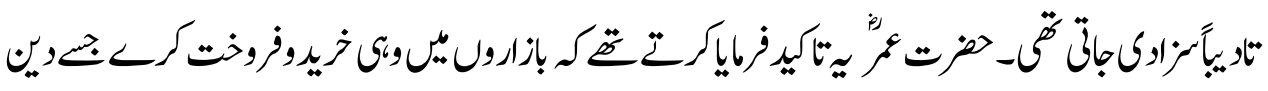

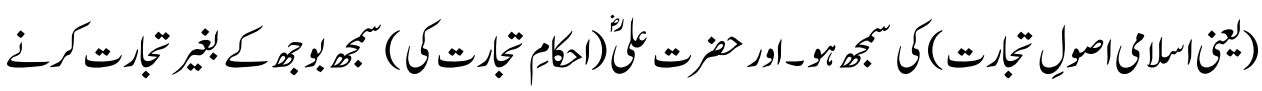

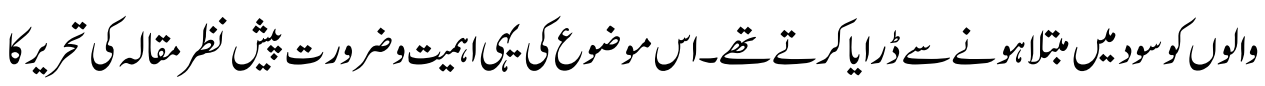

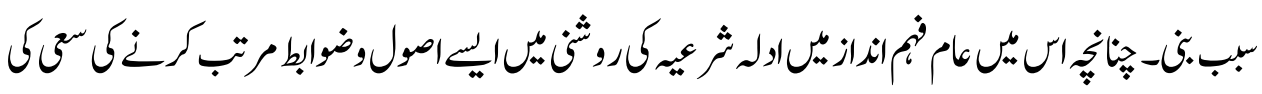

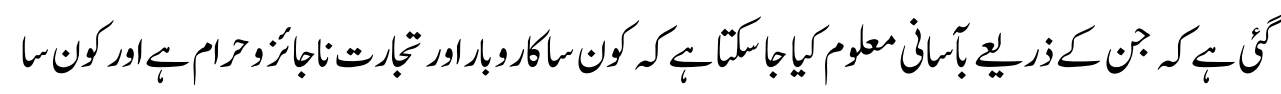
قلالومباح-

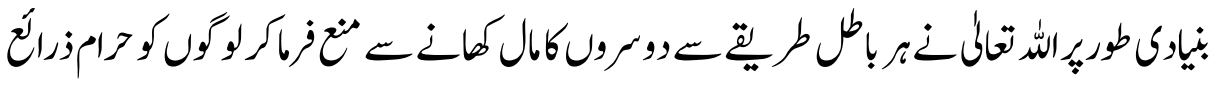

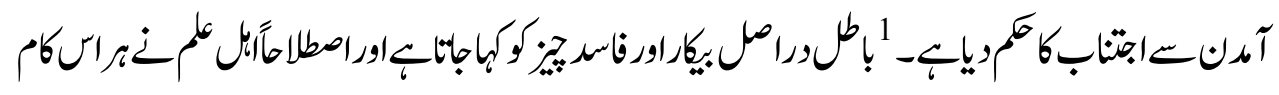

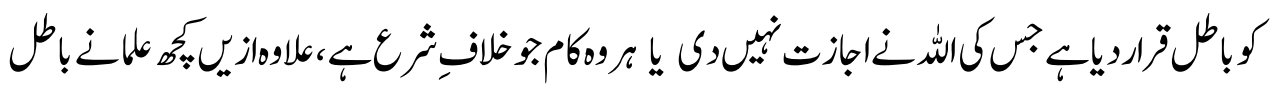

${ }^{1}$ Sūrah Al Baqarah,188 


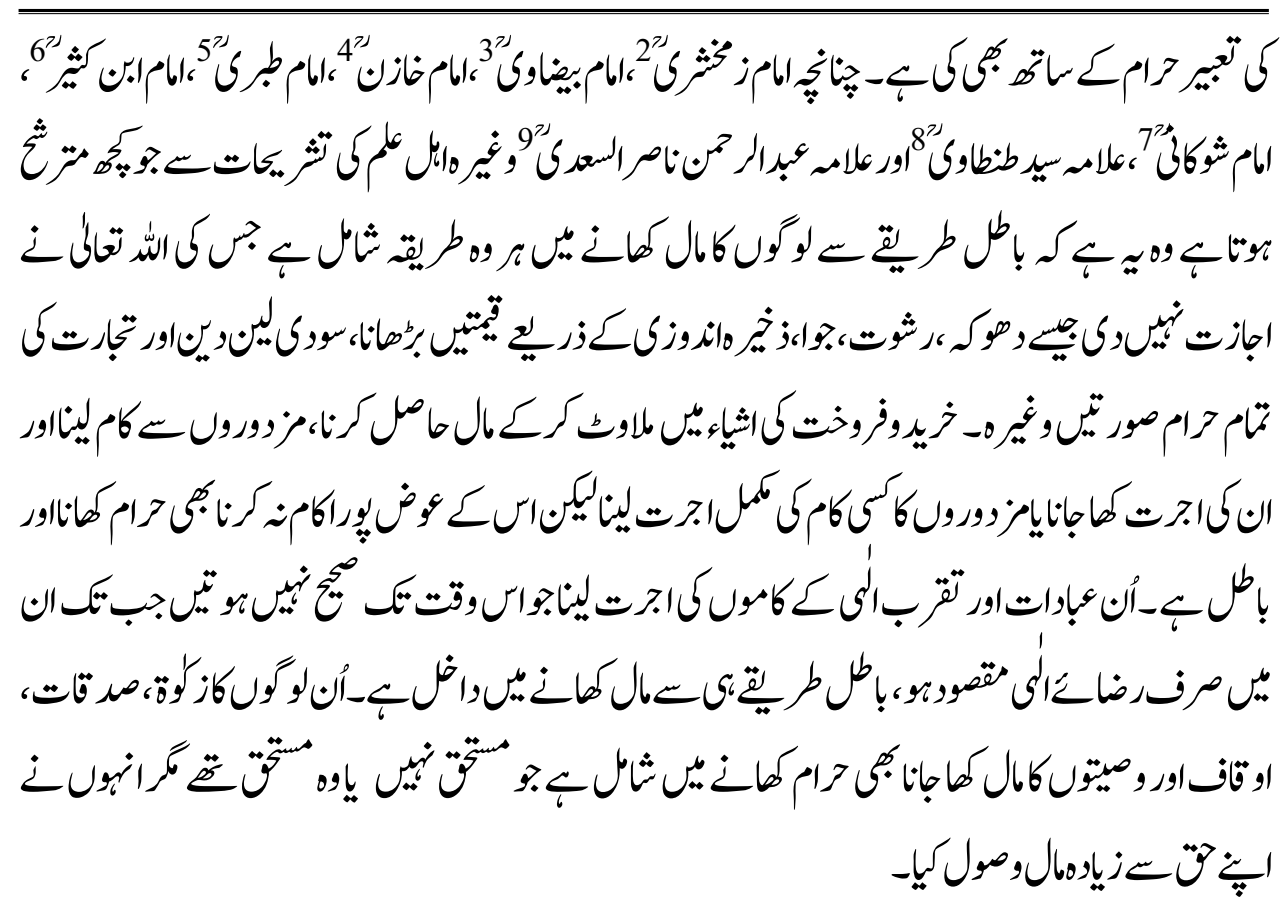

²Al-Zamakhsharī,Abu al-Qāsim Maḥmūd ibn 'Umar , Jār Allāh, AlKashshāf 'an Haqūì at-Tanzīl(Beruit: Dār al Kutub al-'Arabī, 1407AH)1/401.

${ }^{3}$ Al-Bayḍawi, Nașir ad-Din abū -Sa'îd,Anwar al-Tanzil wa-Asrar alTa'wil,(Beirut: Dār Ihyē̄' al Turath al 'Arabī, 1418AH)1/448.

${ }^{4}$ Al-Khāzin, Abū Ja', Alī bin Muḥammad, Tafsīr Al-Khāzin, (Beirut: Dār al Kitāb al 'Arabiyyah, 1415 AH)2/73.

${ }^{5}$ Al-Ṭabarī, Abū Ja'far Muhammad ibn Jarīr, Tafsīr Al-Tabarī,(Beirut: Mo'assasah al Risālah,1420 AH)8/216.

${ }^{6}$ Kathīr, 'Imād al Dīn, Abū al Fidā', Tafsīr al Qur'ān al Azōim, (Beirut: Dār Iḥyā' al Turath al 'Arabī, 1420), 2: 268

${ }^{7}$ Al-Shawkān̄̄ ,Muḥammad bin Alī, Tafsīr Fath al-Qadir,(Beirut: Dār Ibn Kathīr1414 AH)2/130.

${ }^{8}$ Al-Tantawī,Muhammad Sa ${ }^{e ̄ 1}$,Tafsīr Al- wasieț, (Cairo: Dar Nahdh Egypt for Printing 1998) 1/923.

${ }^{9}$ Al-s-Sa di,Abduraḥman bin Nāṣir,TafsirAs-Sa 'di(Beirut:Mo'assasah al Risālah,1420 AH)1/233. 


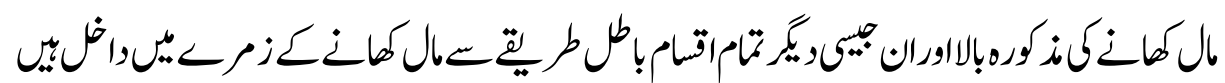

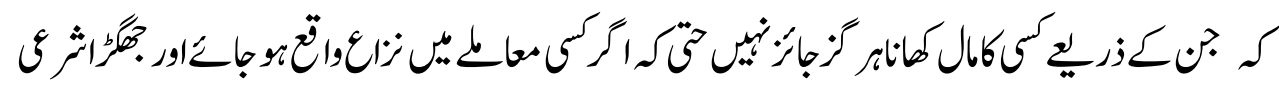

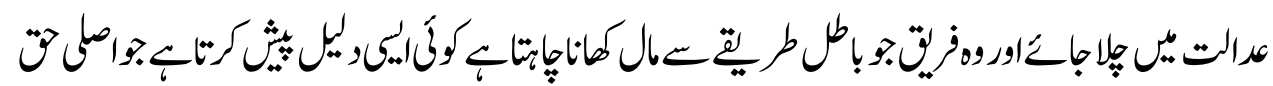

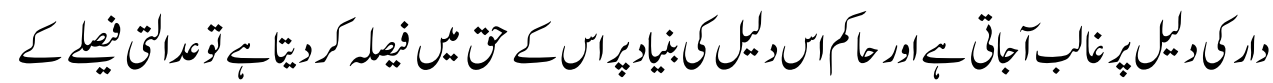

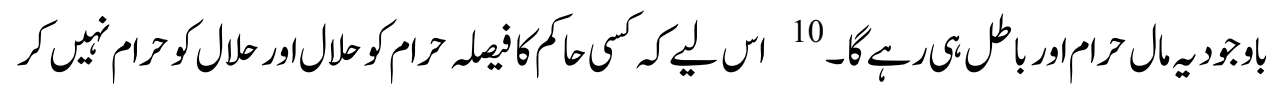

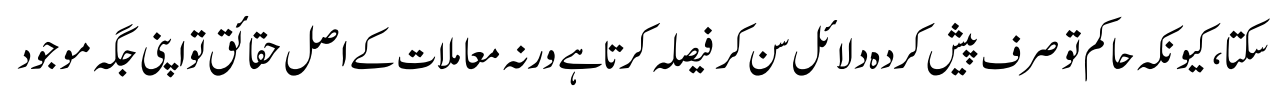

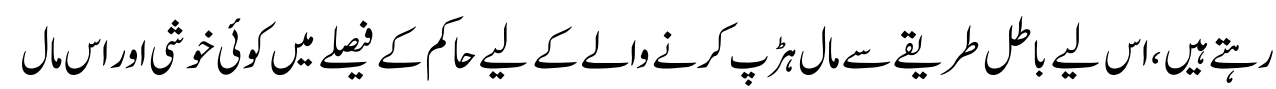

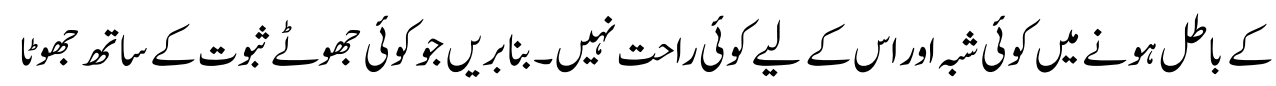

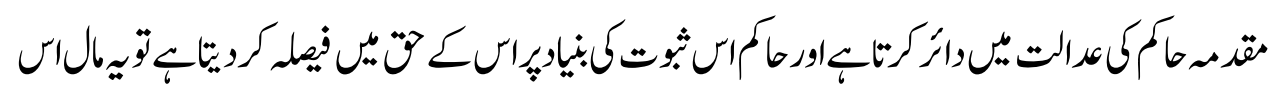

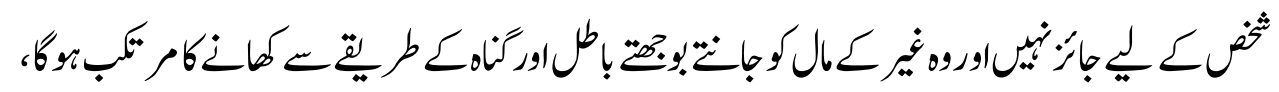

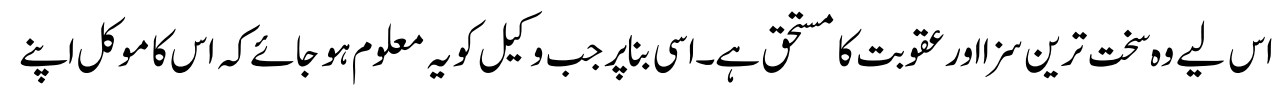

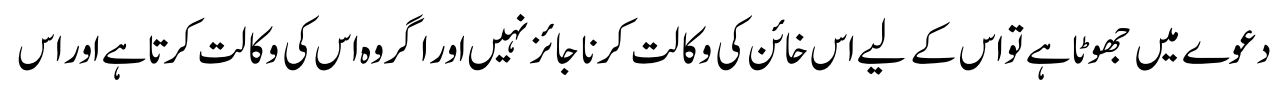

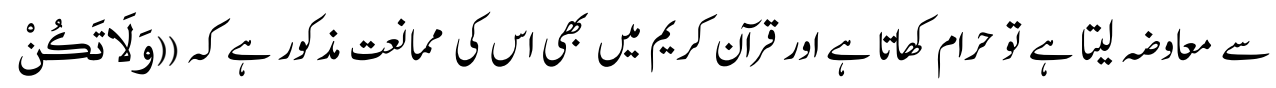

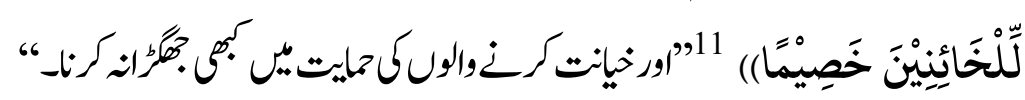

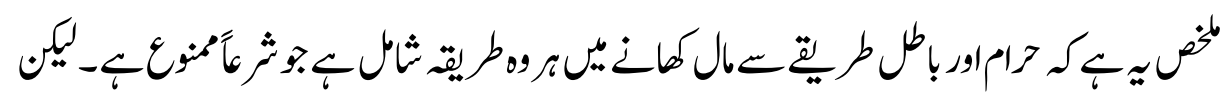

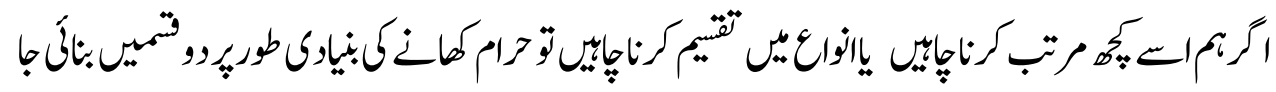

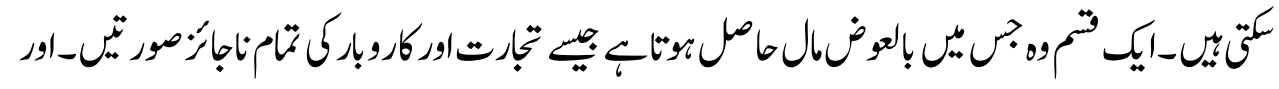

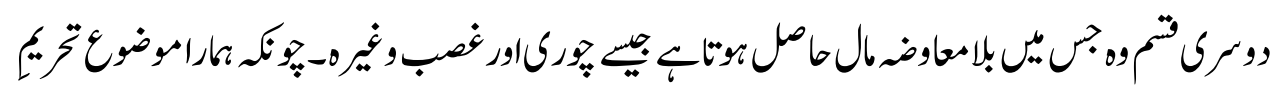

${ }^{10}$ Al Bukhārī, Muḥammad bin Ismā'îl, $\boldsymbol{A l}$ Jāmi' al Ṣaḥ̄ḥ, (Rīyad: Dār Al Salām, 1999), Hadīth:2458.

${ }^{11}$ Sūrah Al Nisā': 105. 


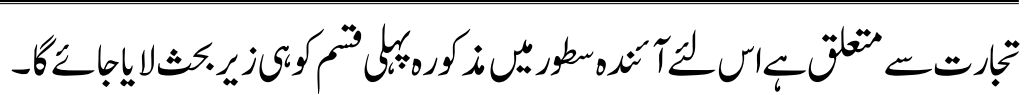

$$
\begin{aligned}
& \text { تخرتمتجارت كبنياركاصول }
\end{aligned}
$$

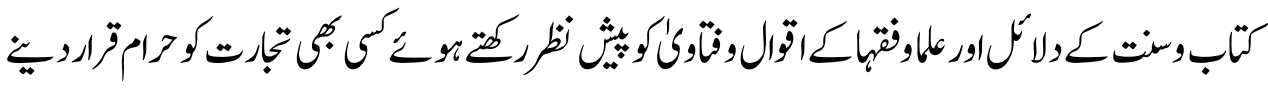

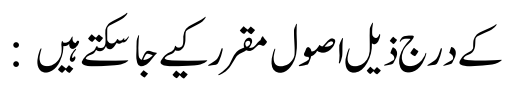
1.

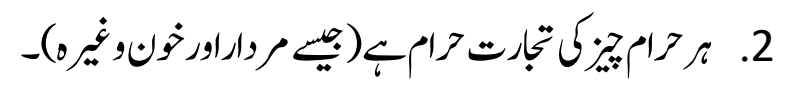

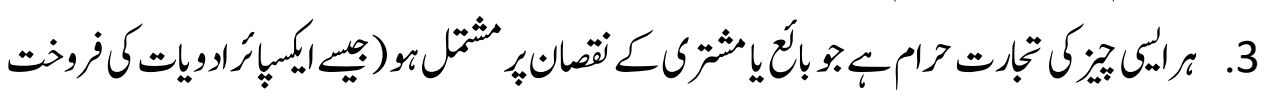

$$
\text { - ونير }
$$

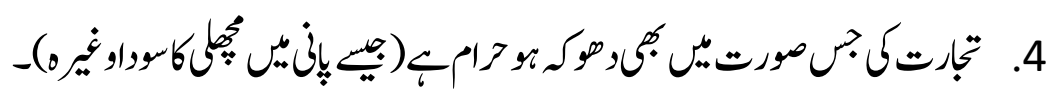

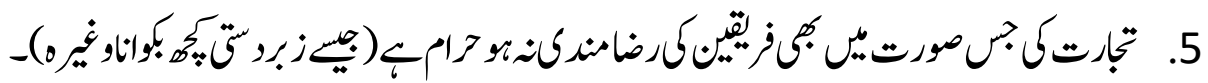
6. تجارت ك.

$$
\text { ونير }
$$

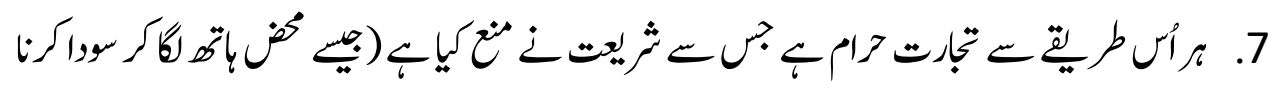

$$
\text { - ونير }
$$

8.

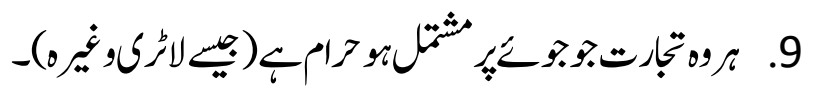

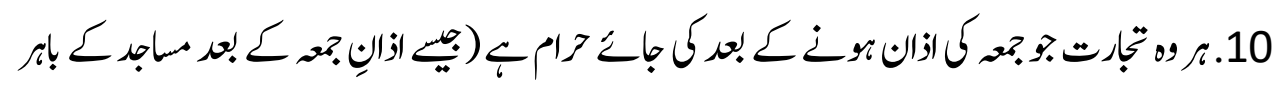

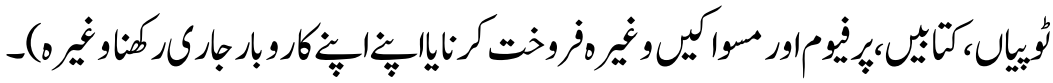

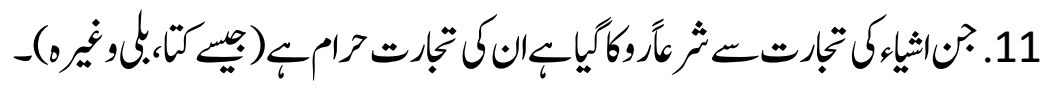

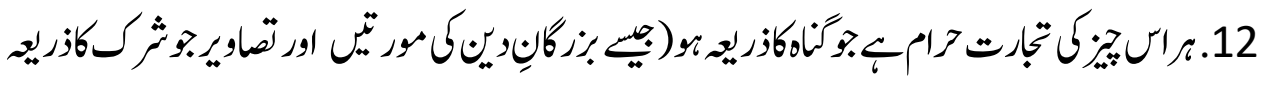

$$
-(4
$$

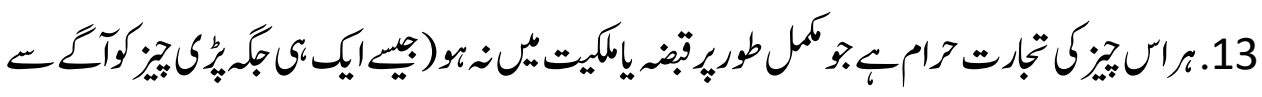




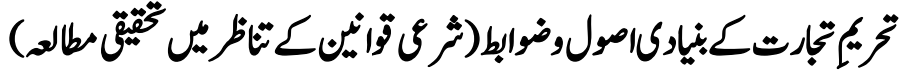

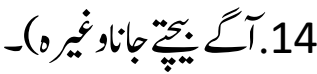

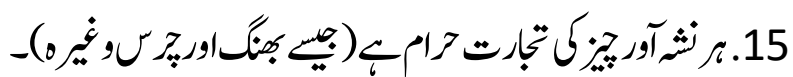

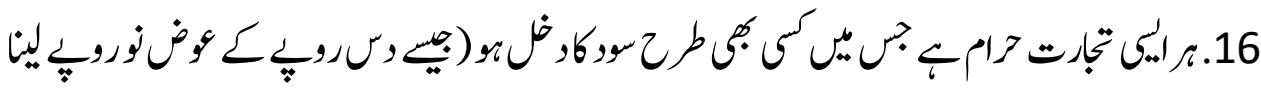

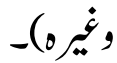

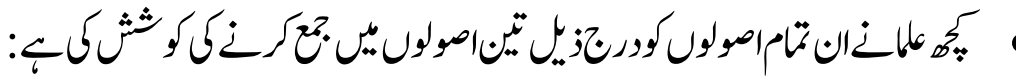

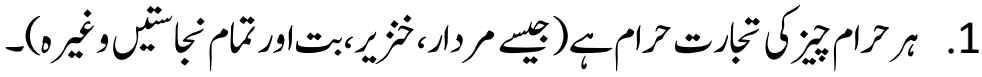

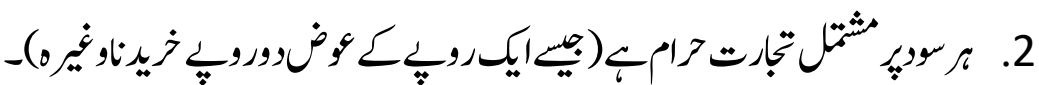

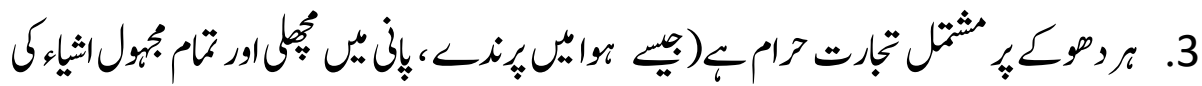

$$
\text { تجارتونئ }
$$

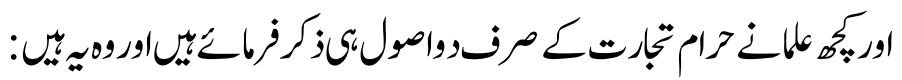

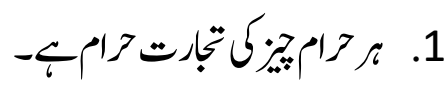

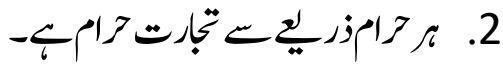

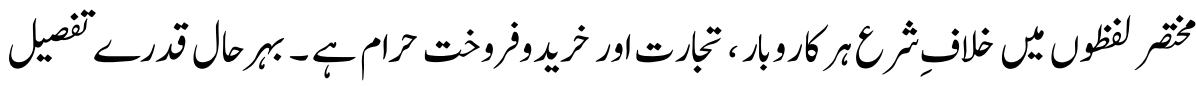

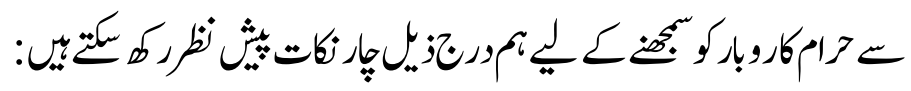

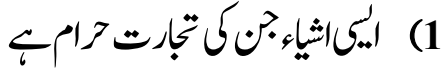

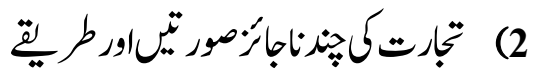

$$
\begin{aligned}
& \text { 3) موركتجارتاورليّنديث }
\end{aligned}
$$

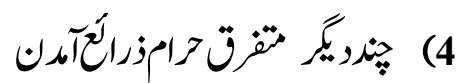

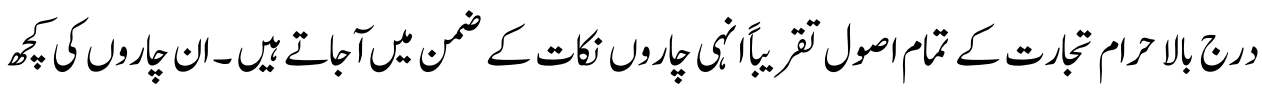

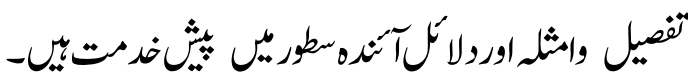

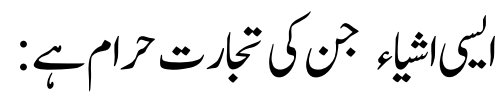

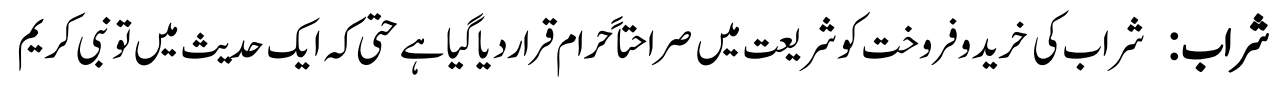




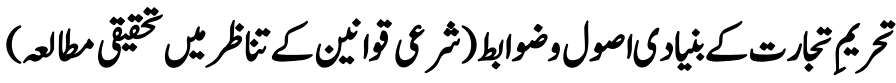

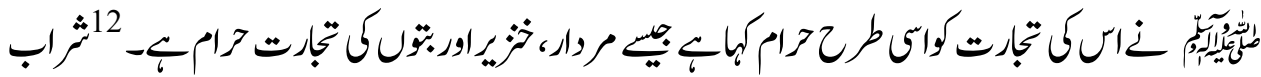

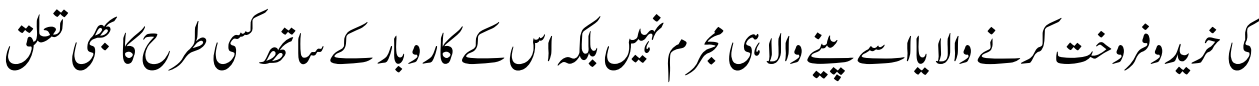

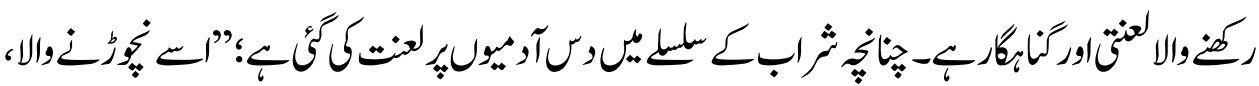

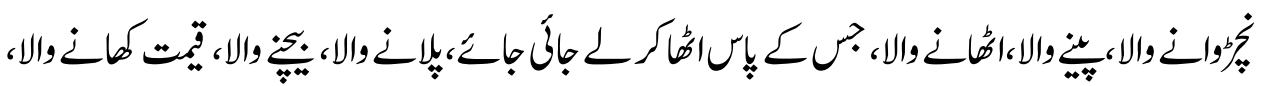

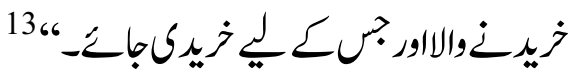

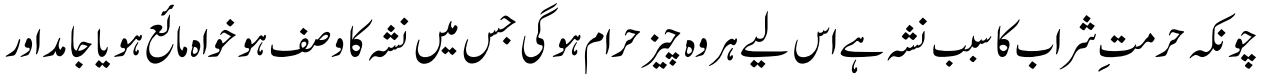

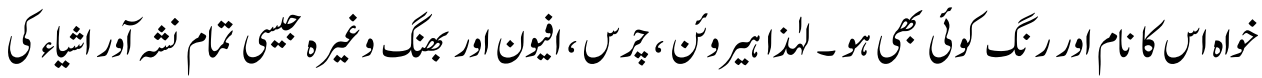

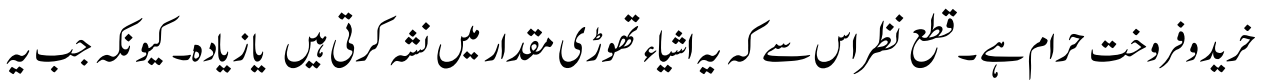

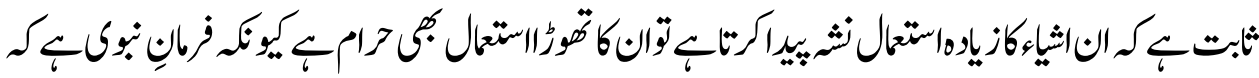

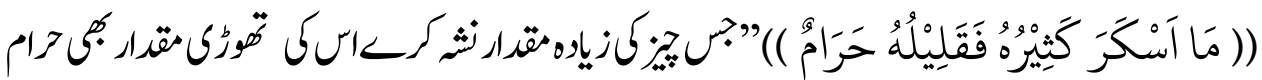
1466 $-6$

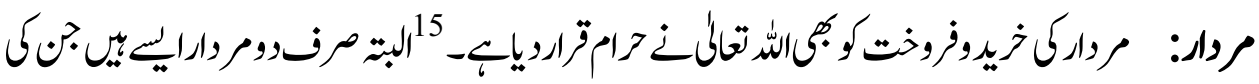

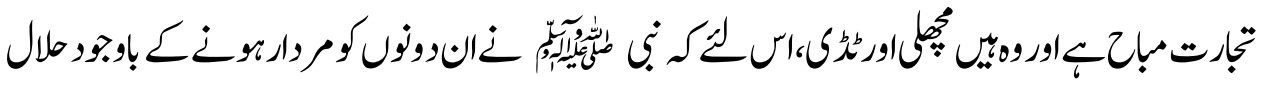
تزارياك-

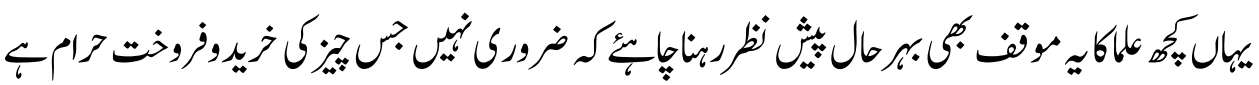

${ }^{12}$ Abū Dāwūd, Sulaymān bin Ash'ath, Al Sunan, (Rīyaḍ: Dār Al Salām, 1997), Hadīth:3486.

${ }^{13}$ Al Tirmidhī, Muhammad bin 'Esa $\boldsymbol{A l}$ Jāmi',(Rīyad: Dār Al Salām, 1416 Ah)Hadīth \#1295.

${ }^{14}$ Al-Nasā'ī, Abū `Abd ar-Raḥmān Aḥmad ibn Shu`ayb, Sunan Al-Nas̄̄̄'̄ (Rīyad: Dār Al Salām, 1418) Hadīth \#5607.

${ }^{15}$ Ibn Mājah,Muhammad bin Yazīd, Sunan Ibn Mājah, (Rīyaḍ: Dār Al Salām, 1416) Hadīth \#2167.

${ }^{16}$ Sunan Ibn Mājah, Hadīth \#3314 


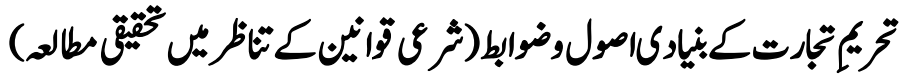

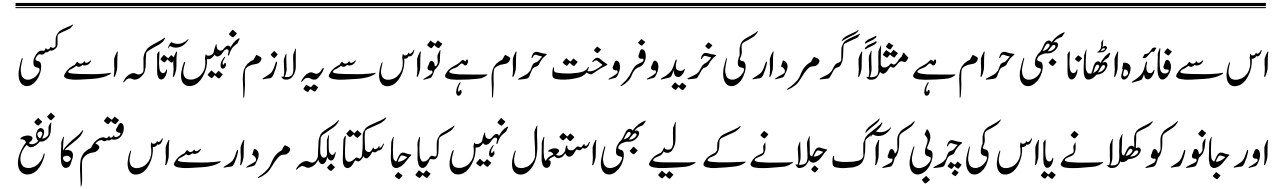

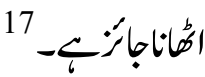

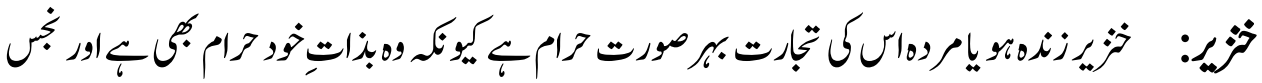

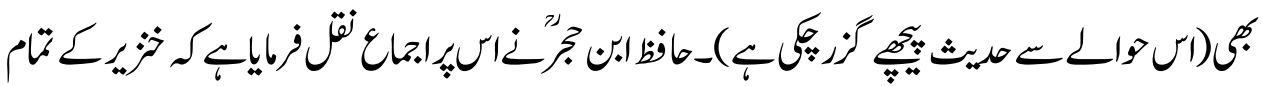

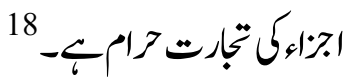

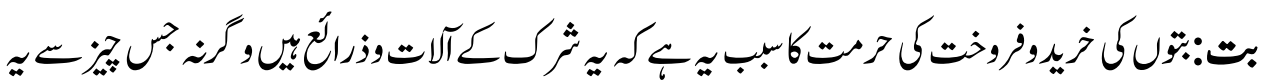

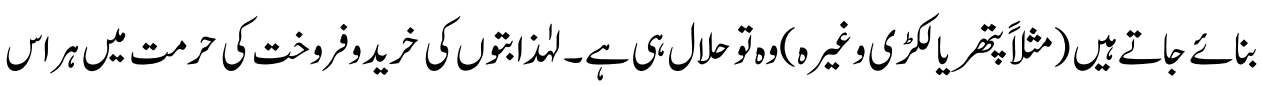

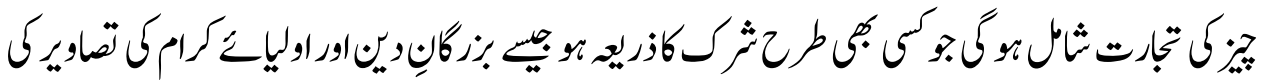

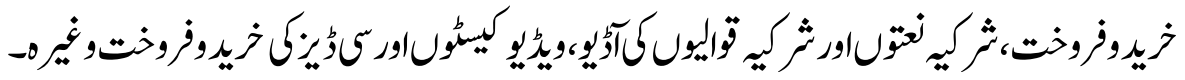

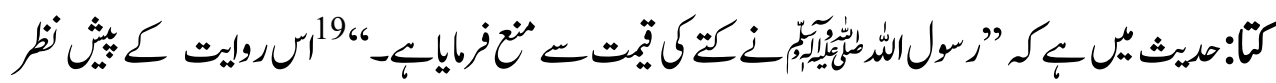

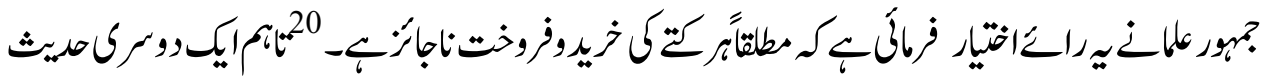

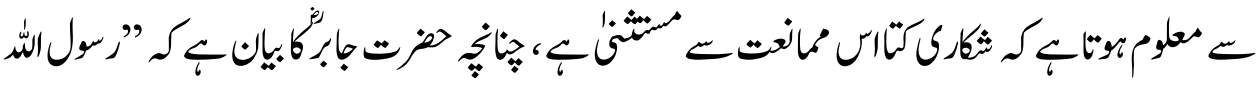

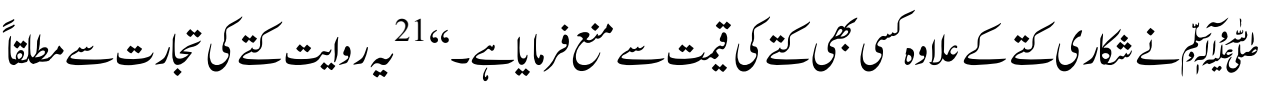

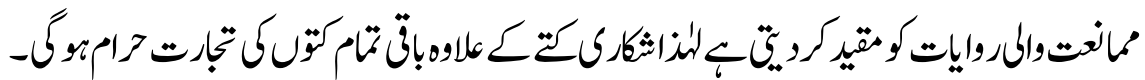

${ }^{17}$ Ibn Qayyim,Muhammad Ibn Abī Bakr, Shams al-Dīn, Zad al-Ma'ad Fi Hadyi Khair Al 'Ibaad (Beirut: Mo'assasah al Risālah,1415 AH)4/242.

${ }^{18}$ Ibn Hajar al- 'Asqalānī, Shihābud-Dīn Abul-Fạ̣l Aḥmad ibn Nūrud-Dīn 'Al̄̄, Fatḥ al-Bārī fì Sharh Șaḥ̄h al-Bukhārī, ( Beurit: Dār al M'arifah 1379 AH) $5 / 178$.

${ }^{19}$ Sahīh al-Bukhārī , Hadīth \#2237.

${ }^{20}$ Al-Shawkānī ,Muḥammad bin Alī, Nayl al-Awtar,(Cairo:Dār Al-ḥadith 1413)3/512.

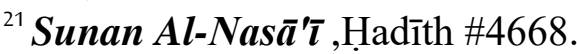




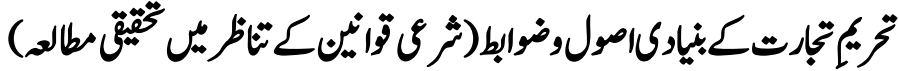

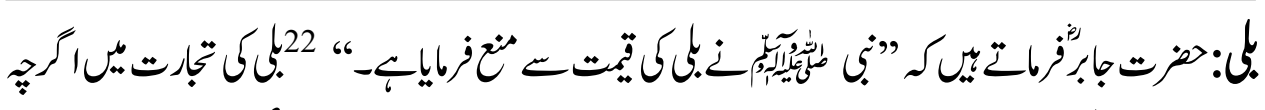

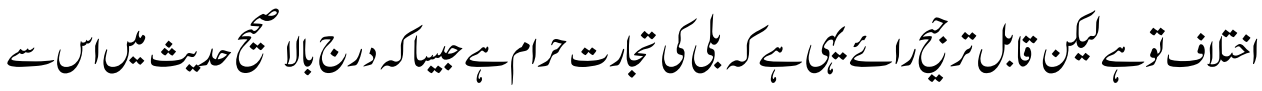
ك

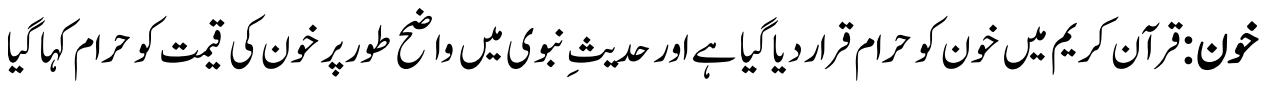

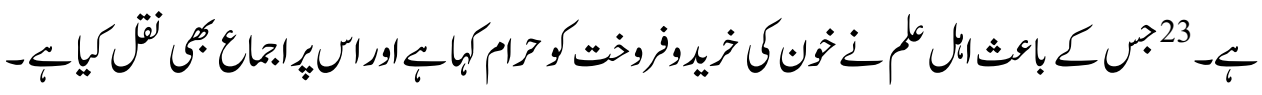

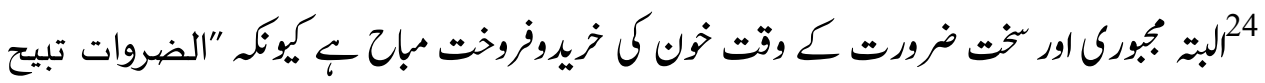

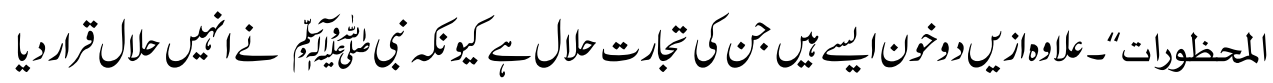

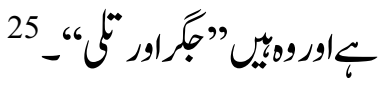

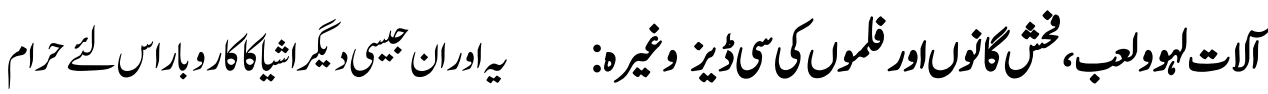

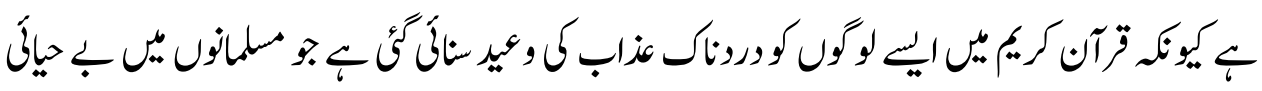

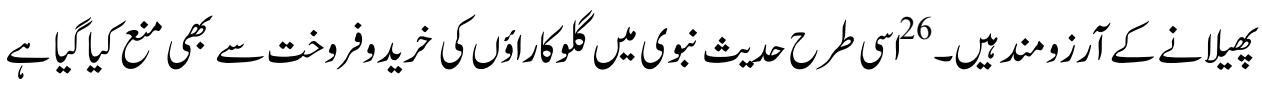

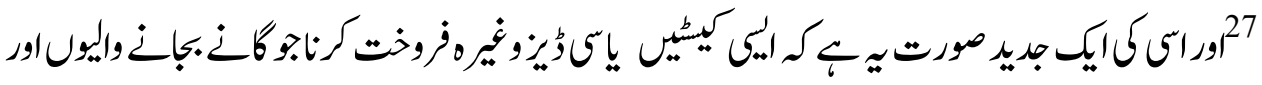

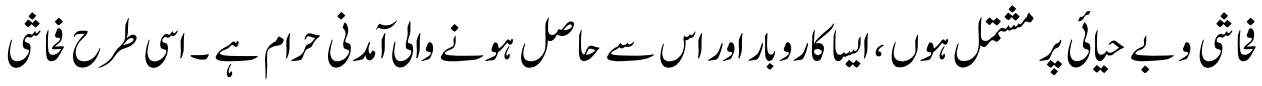
كهيل

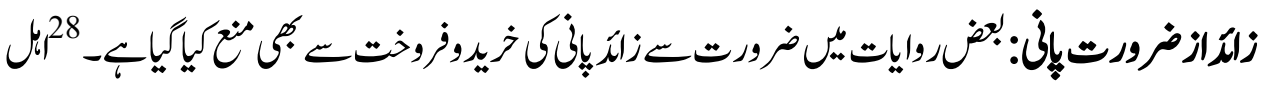

${ }^{22}$ Muslim bin Hajjāj, Al Jāmi’ al Ṣaḥịh, (Rīyaḍ:Dār al Salām, 1987), Hadīth: 1569.

${ }^{23}$ Șahīh al-Bukhārī , Hadīth \#2086

${ }^{24}$ Nayl al-Awtar: 5/238, And, Fath al-Bārī:5/180.

${ }^{25}$ Sunan Ibn Mäjah, Hadīth \#3314.

${ }^{26}$ Al-Noor:19

${ }^{27}$ Jämi'al Tirmidhī, Hadīth \#1282.

${ }^{28}$ Șaḥịh Al-Muslim, Hadīth \# 1565. 


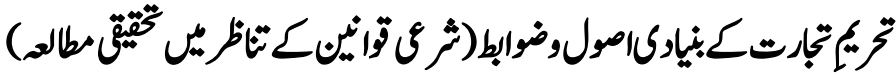

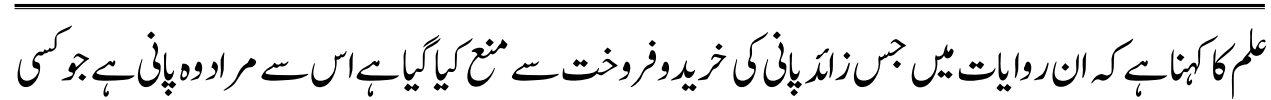

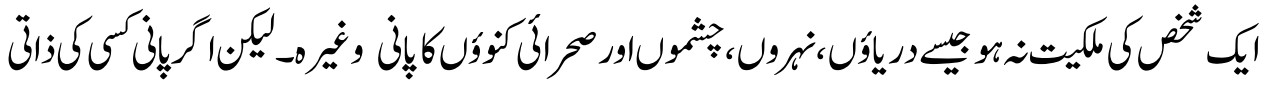

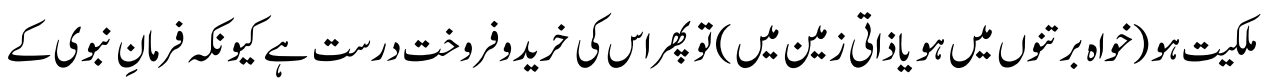

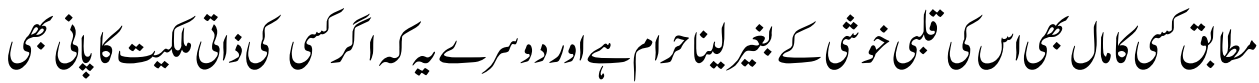

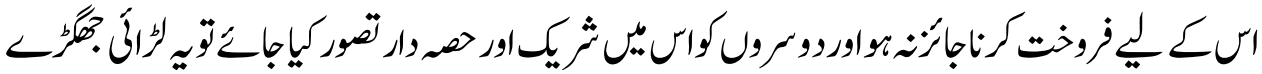

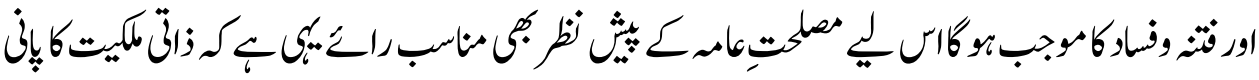

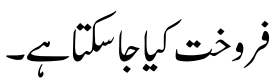

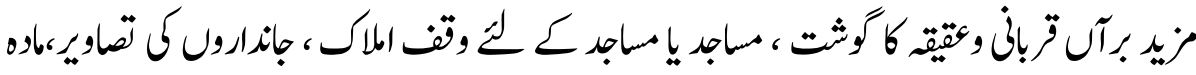

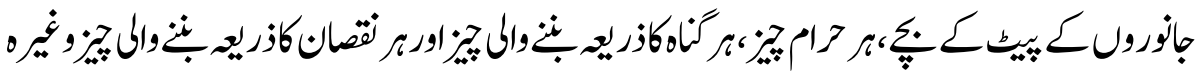

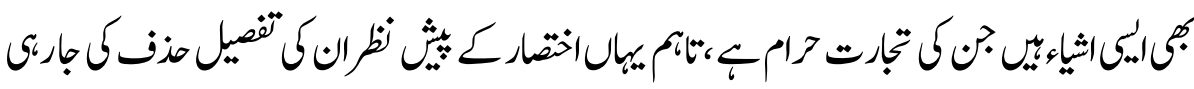

$$
\begin{aligned}
& -4
\end{aligned}
$$

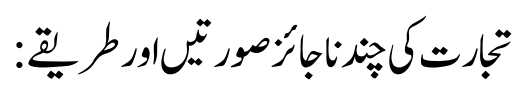

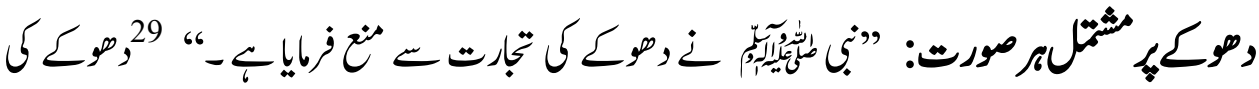

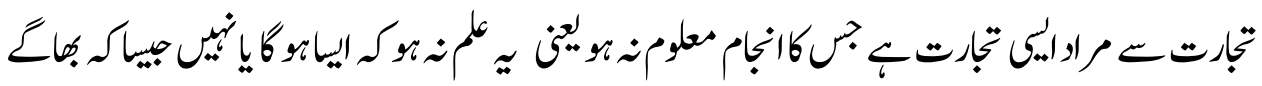

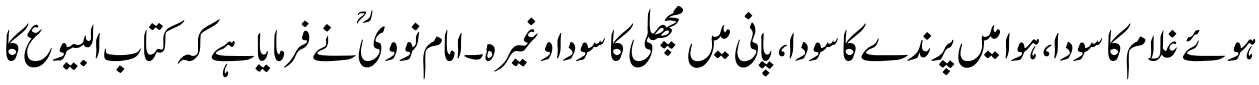

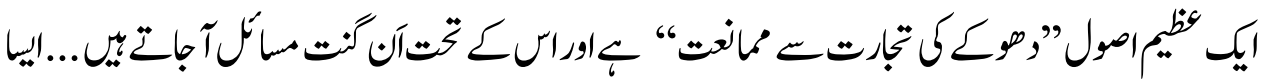

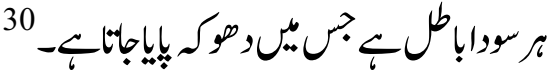

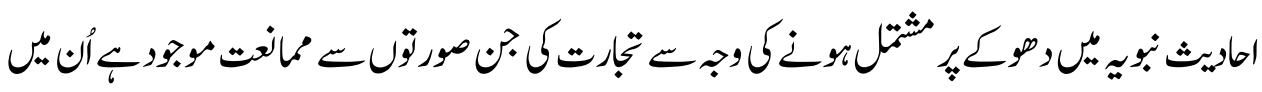

${ }^{29}$ Sahīị Al-Muslim, Hadīth \# 1513.

30 Al Nawawī, Yaḥyāa bin Sharf, $\boldsymbol{A l}$ Minhāj $\boldsymbol{f} \tilde{i}$ Sharh Sạạ̄h Muslim, (Beirut: Dār Ihỵā’ al Turath al 'Arabī, 1428), 5/416. 


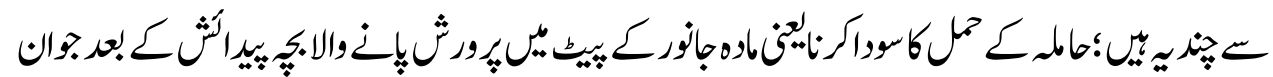

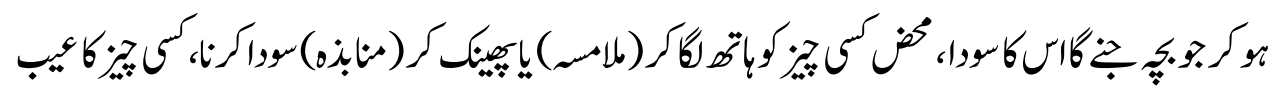
تُهِ

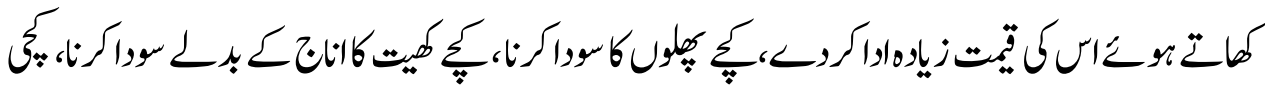

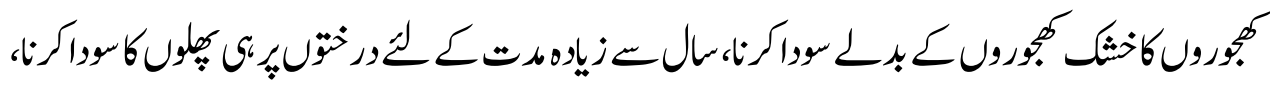

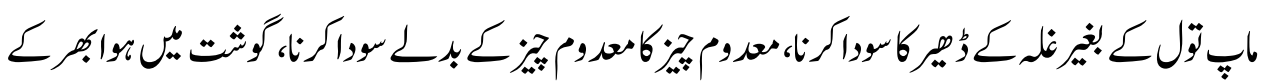

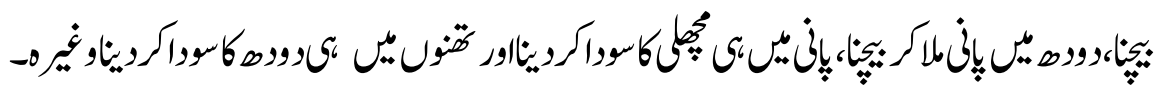

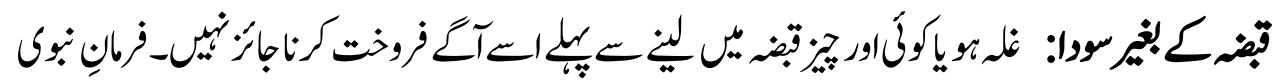

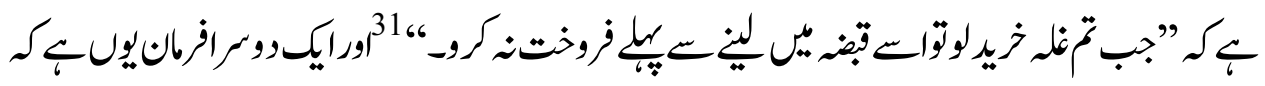

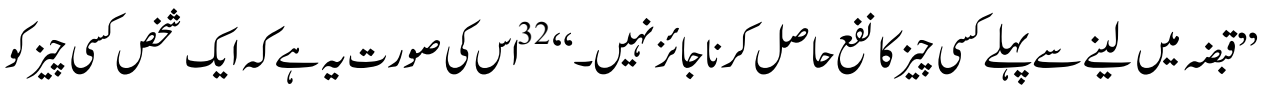

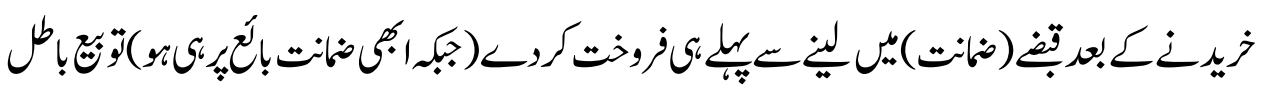

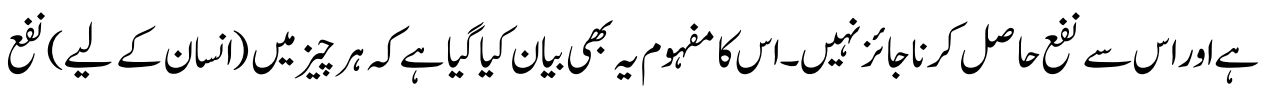

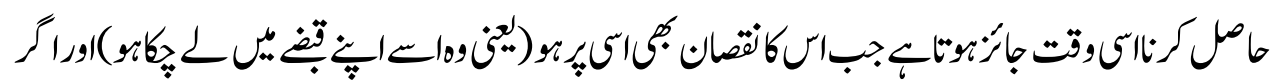

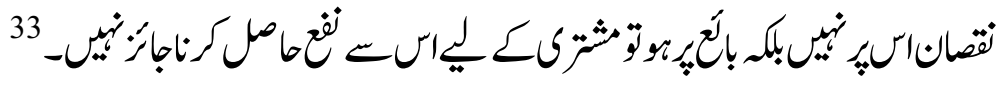

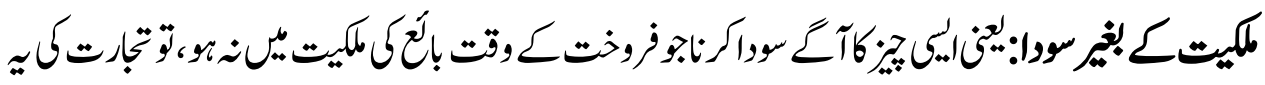

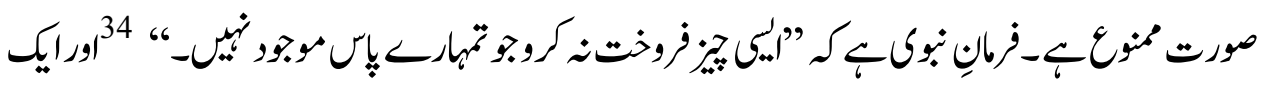

${ }^{31}$ Şahīh Al-Muslim, Hadīth \# 1529.

${ }^{32}$ Sunan Ibn Mäjah, Hadīth \#2188.

${ }^{33}$ Nayl al-Awtar: 3/555.

${ }^{34}$ Sunan Abī Dāwō̄d, Ḥadīth:3503. 


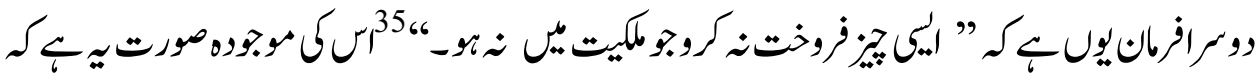

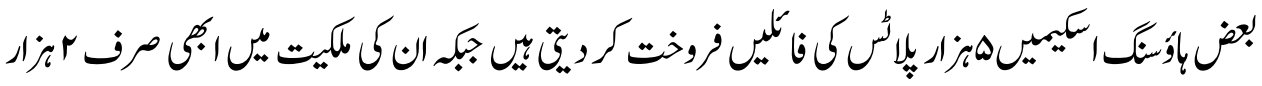

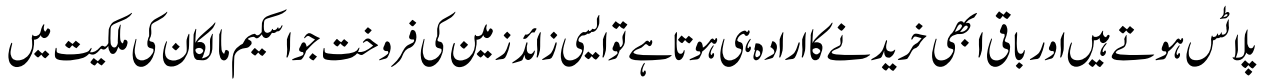

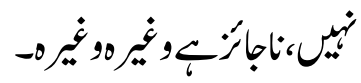

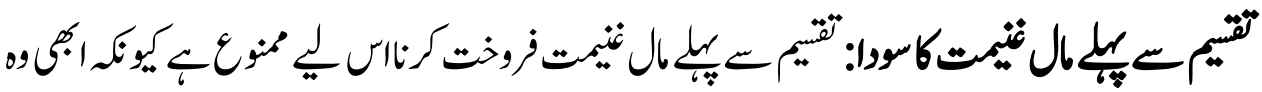

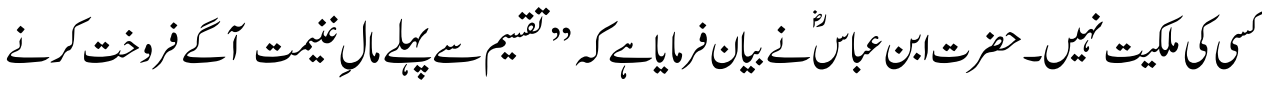

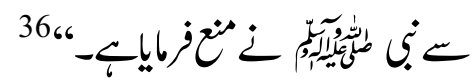

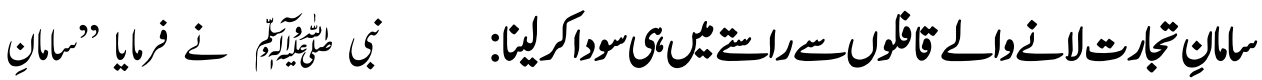

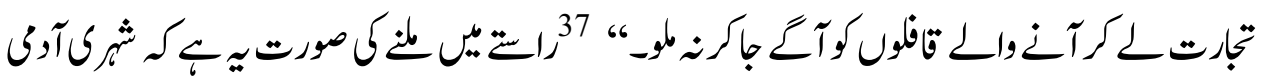

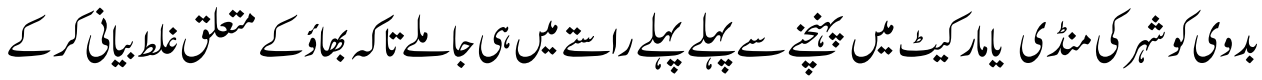

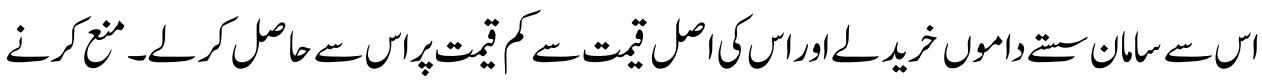

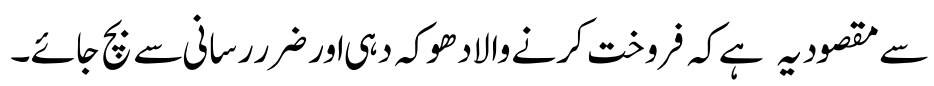

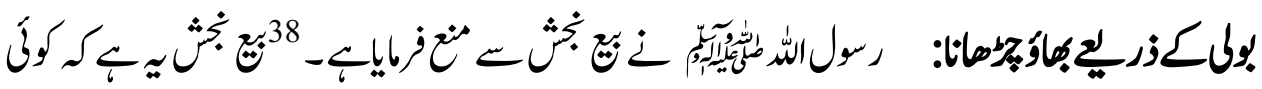

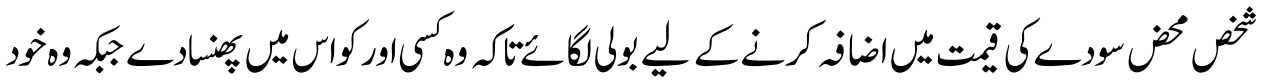

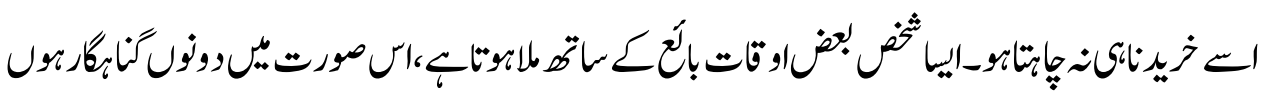

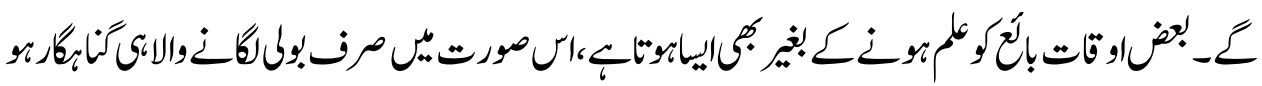

${ }^{35}$ Bayhaqī, Aḥmad bin Ḥusaīn,Sunan Al Kubra(Beirut: Dār al Kutub al 'Ilmiyyah, 1424 Ah)5/554.

${ }^{36}$ Āhmad Bin Hambal, Al-Musnad,( Beirut: Mo'assasah al Risālah,1421 AH) Hadīth:9909.

${ }^{37}$ Ṣaḥịh al-Bukhārī , Hadīth \#2186.

${ }^{38}$ Saḥ̄h al-Bukhārī , Hadìth \#2142. 


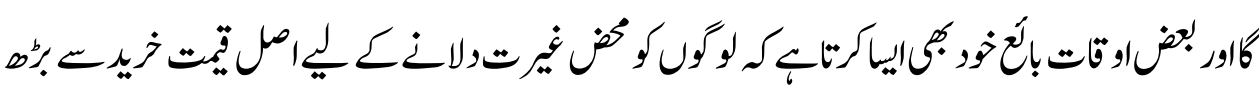

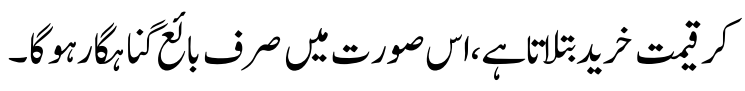

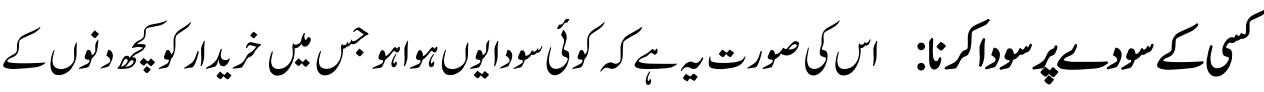

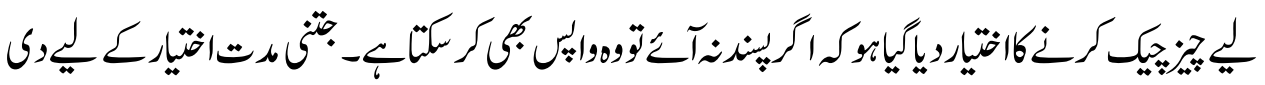

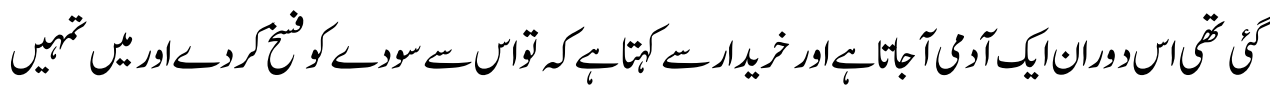

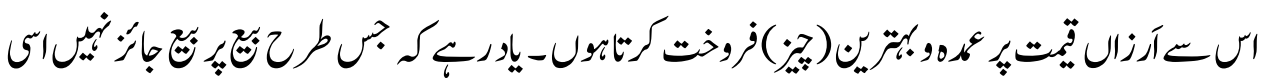

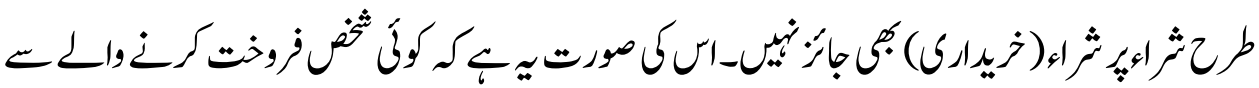

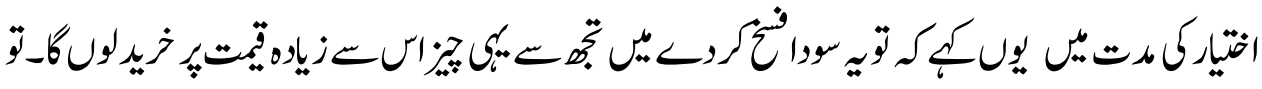

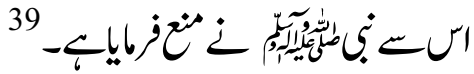

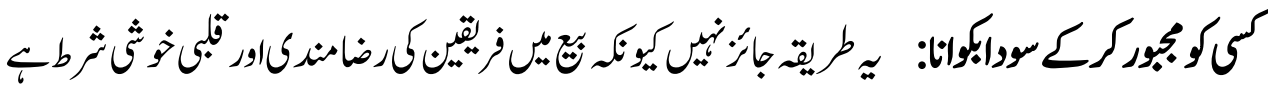

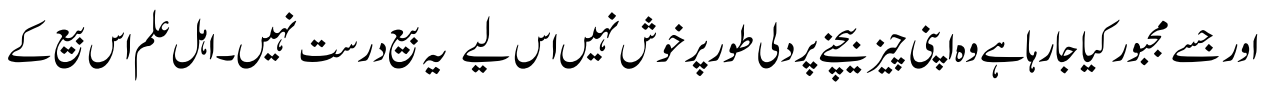

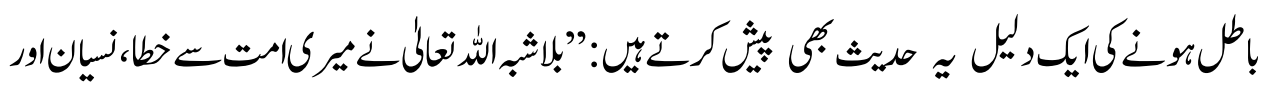

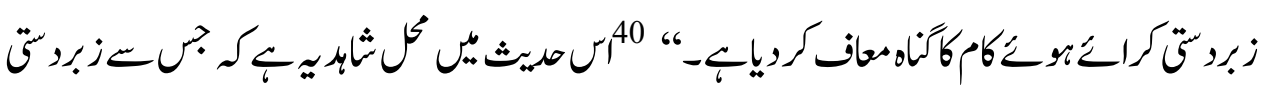

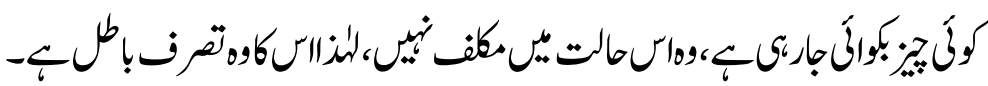

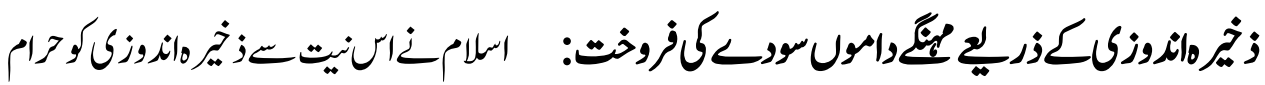

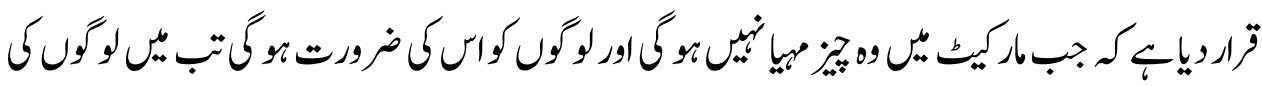

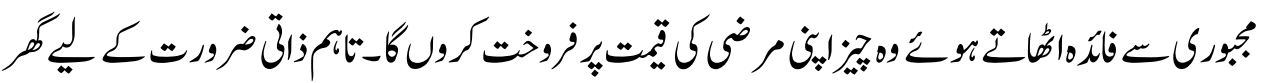

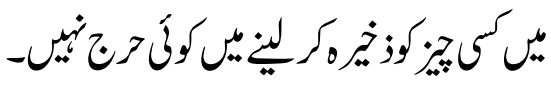

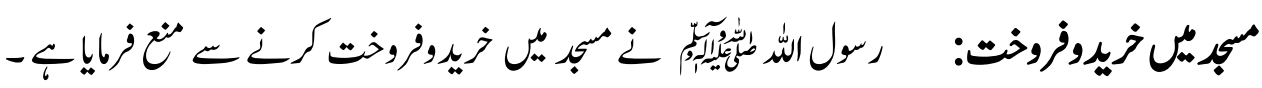

${ }^{40}$ Sunan Ibn Mājah, Hadīth \#2043. 


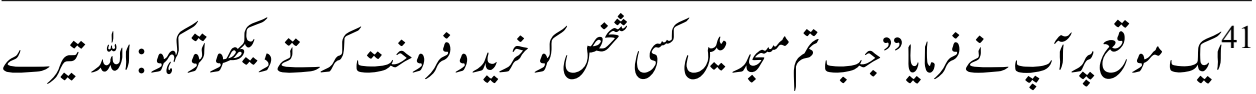

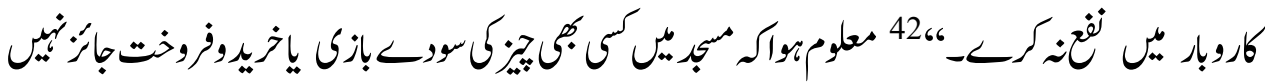

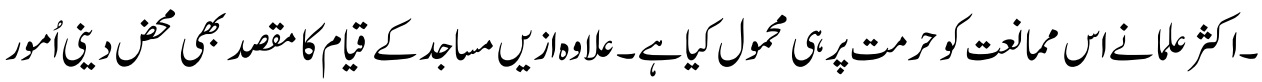

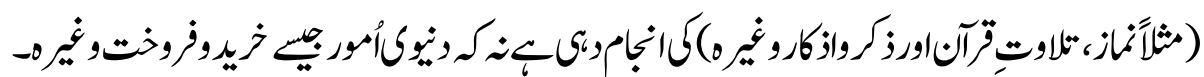

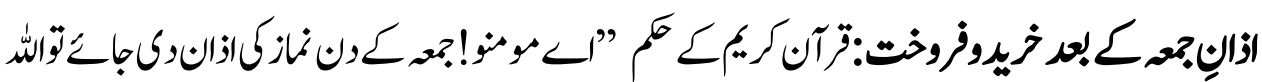

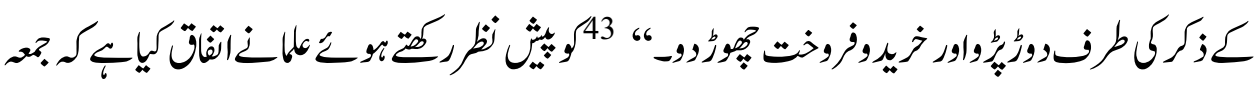

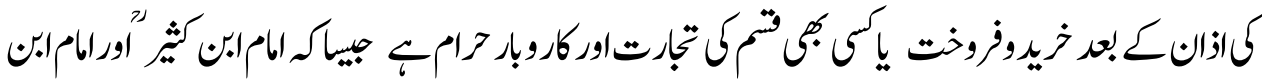

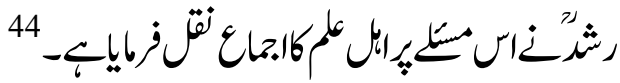

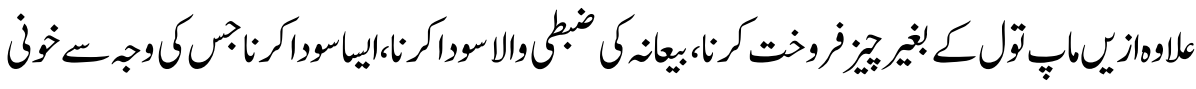

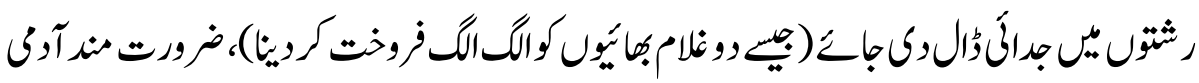

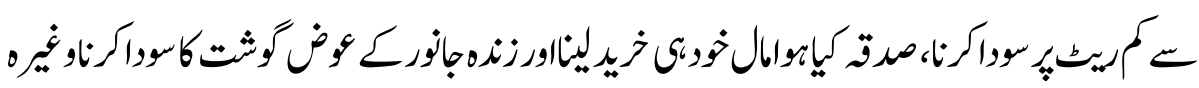

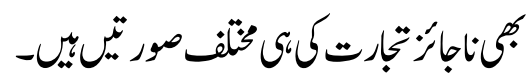

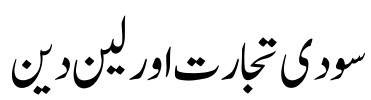

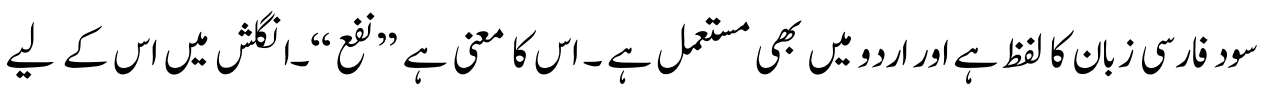
Interest

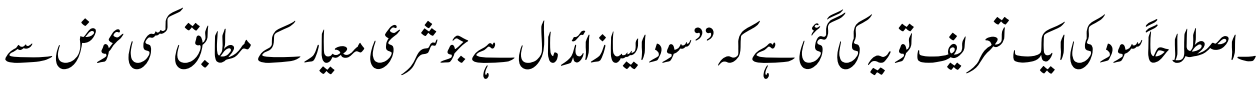

\section{${ }^{41}$ Sunan $A \bar{b} \bar{\imath} \mathbf{D a} w \bar{u} d$, Hadīth:1079.}

${ }^{42} J \mathbf{a} m i$ 'al Tirmidhī, Hadīth \#1321.

${ }^{43}$ Al-Jum 'ah:9

${ }^{44}$ Tafsīr Ibn Kathīr, 5/122., Ibn Rusad, Abu Al-Walīd Muhammad bin Aḥmad, Bidāt-ul-Mujtahid, Dār Al-ḥadith Al:Cairo,)4/169. 


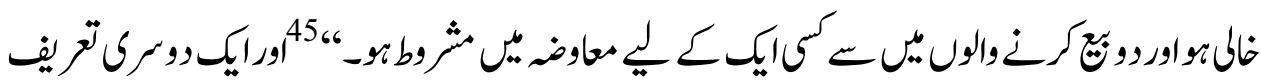

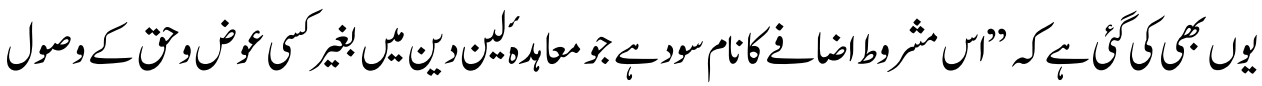

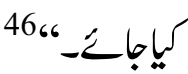

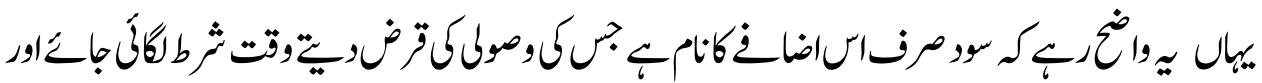

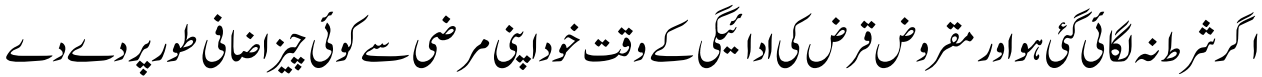

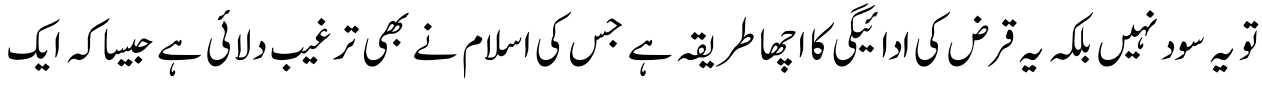

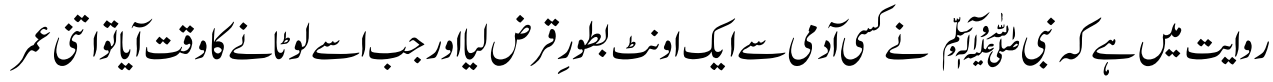

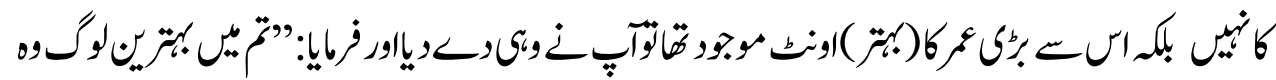

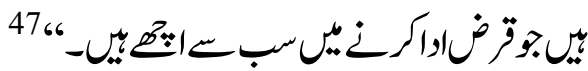

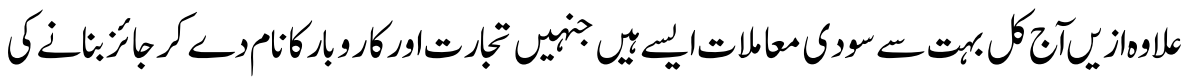

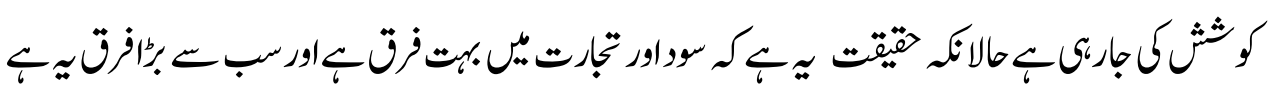

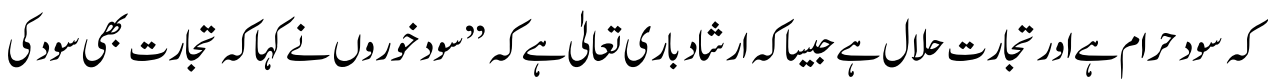

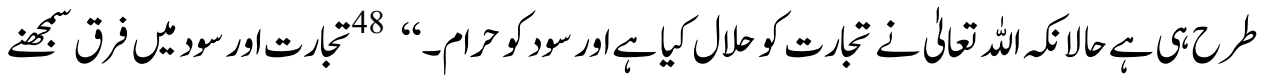

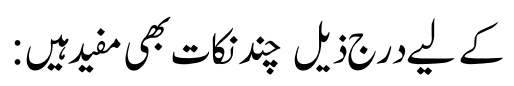

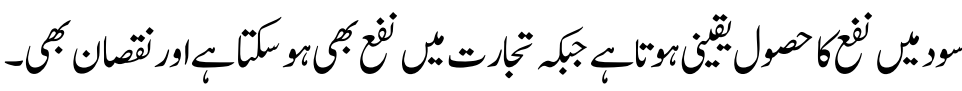

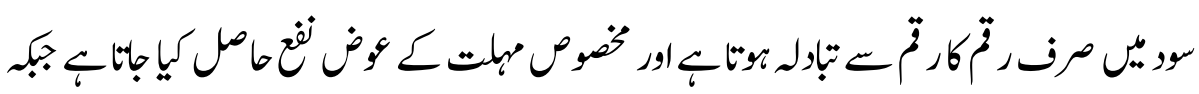

${ }_{45}$ S $^{e}$ adī,Abū Habīb,Dr,Al-Qamoos Al-Fiqhī,(Dimicus: Dār Al-Fikar 1408)P:143.

${ }^{46}$ Al-Mabsut, Muhammad b. Ahmad b. Abi Sahl Abu Bakr al-SarakhÉ, Kitab Dar al Maarifah, Beirut 12/ 192

${ }^{47}$ Șaḥīh al-Bukhārī , Hadīth \#2305.

${ }^{48}$ Sūrah Al Baqarah,275 


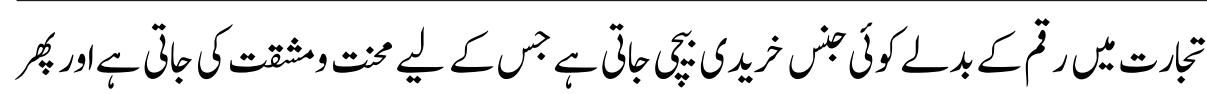

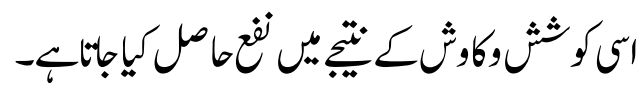

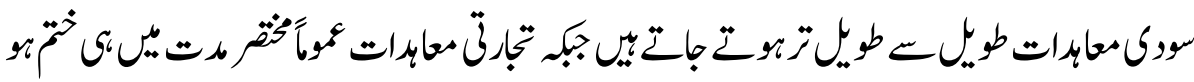
جإتبي

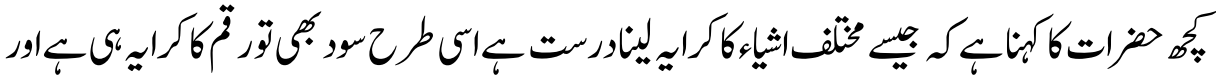

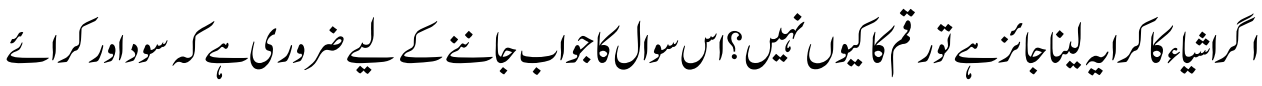

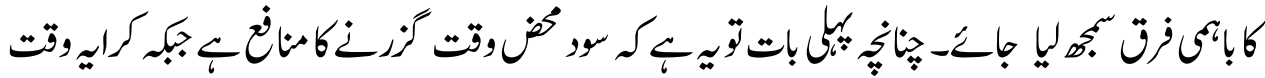

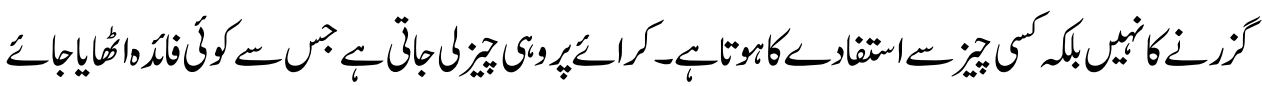

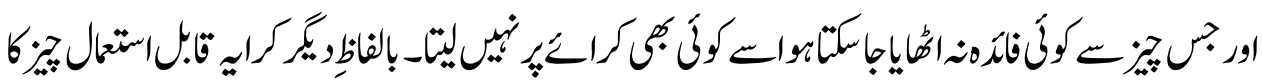

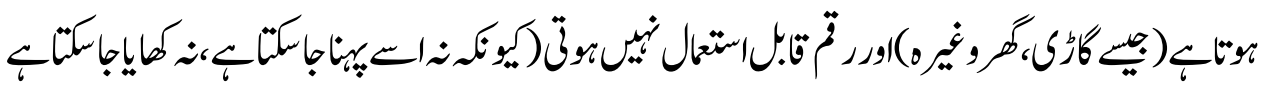

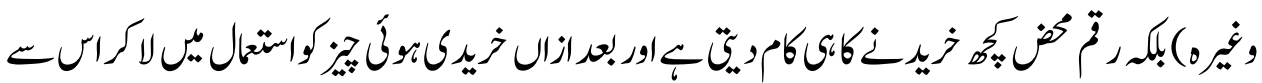

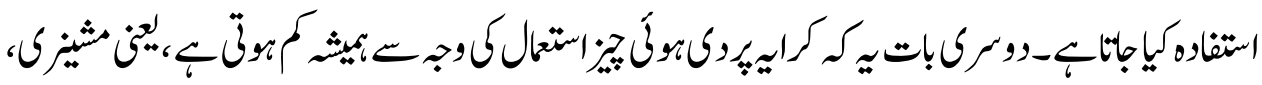

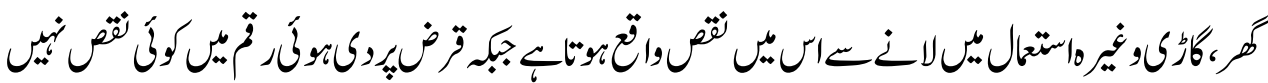

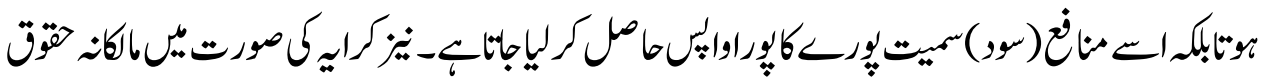

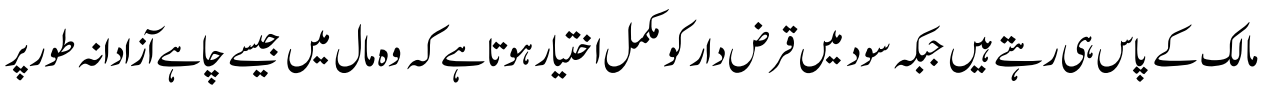
تصرفكـ

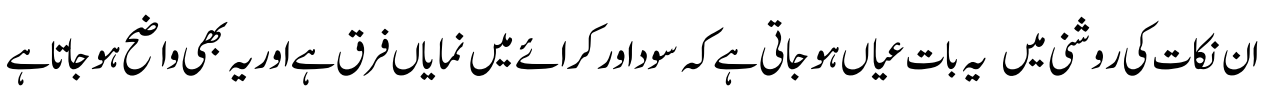

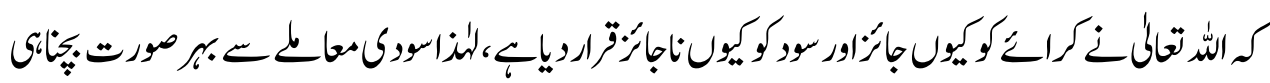

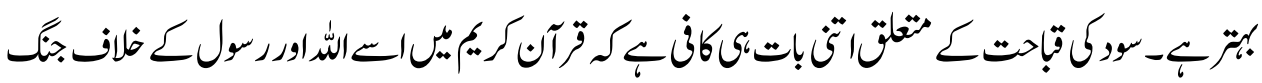

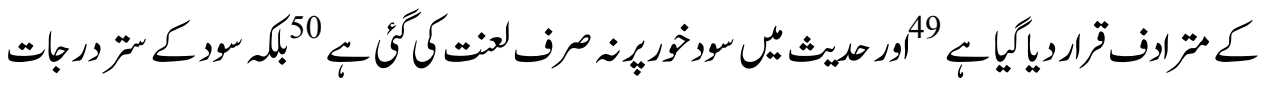

${ }^{49}$ Sūrah Al Baqarah, 279 


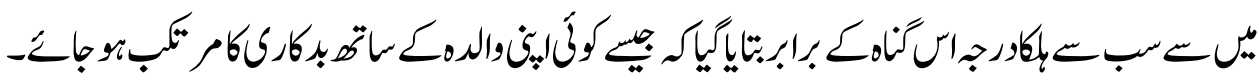

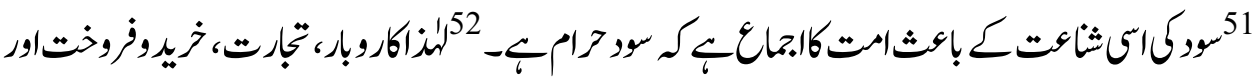

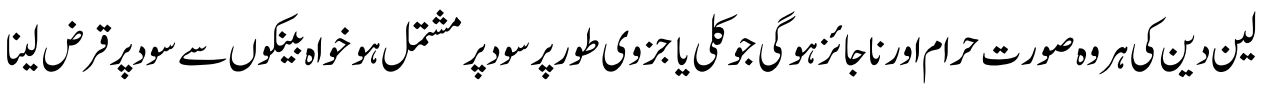

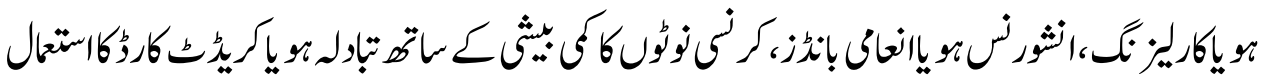
ونير في ونير

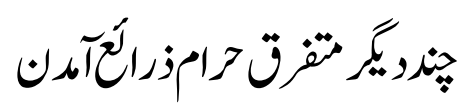

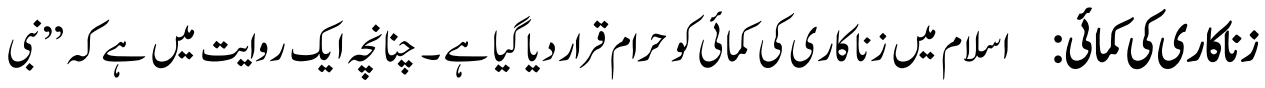

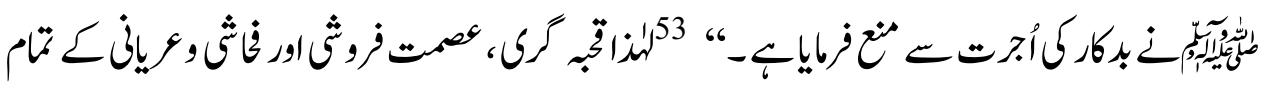
كاروبار קرامثيل-

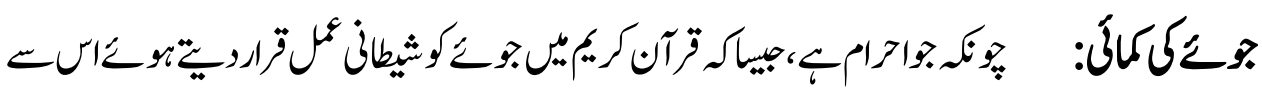

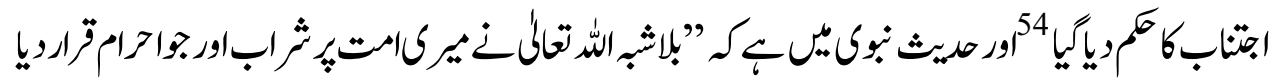

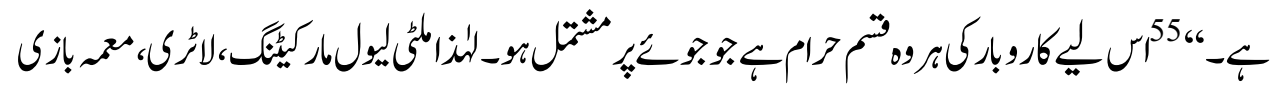

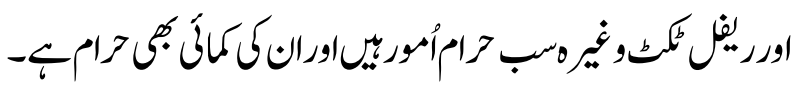

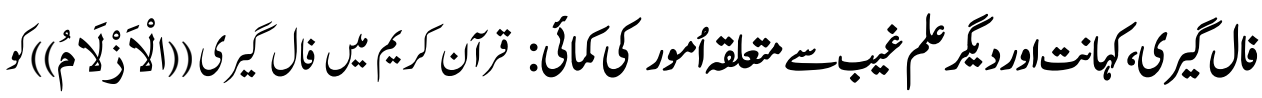

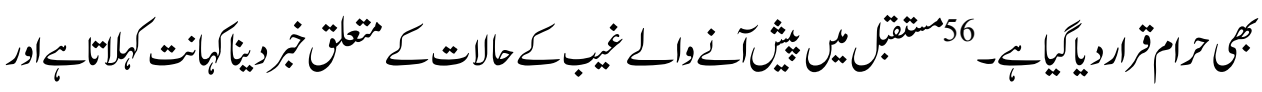

${ }^{50}$ Şahīh Al-Muslim, Hadīth \# 1597.

${ }^{51}$ Sunan Ibn Mäjah, Hadīth \#2274

${ }^{52}$ Mausu'ah alijma fi-fiqh al-Islami, Dar ul Tauzee li Nasr w Tauzee, Riyadh 4/21

${ }^{53}$ Șahịị al-Bukhārī , Ḥadīth \#2930

${ }^{54}$ q. Sūrah Al Mā’idah, 90

${ }^{55}$ Musnad Āḥmad Hadīth :6564.

56. Sūrah Al Mā’idah, 90 


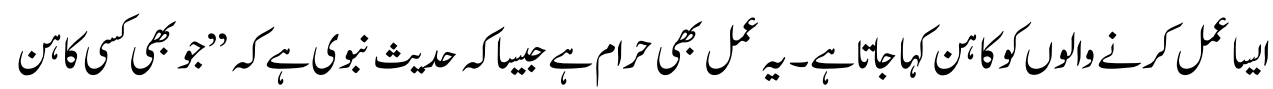

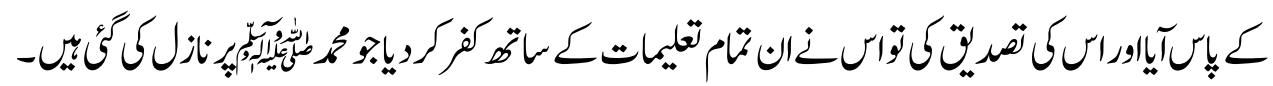

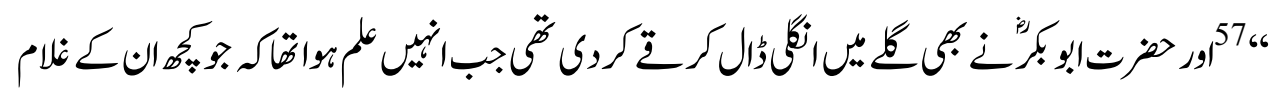

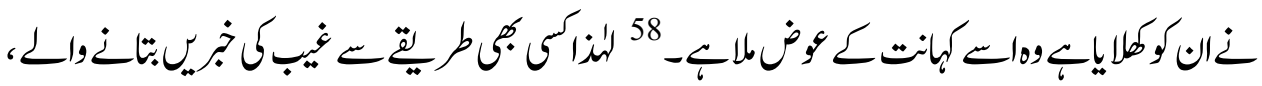

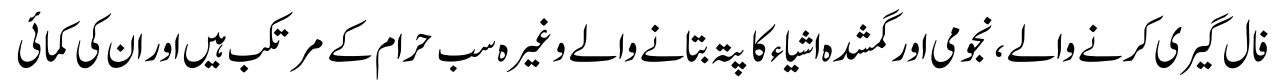

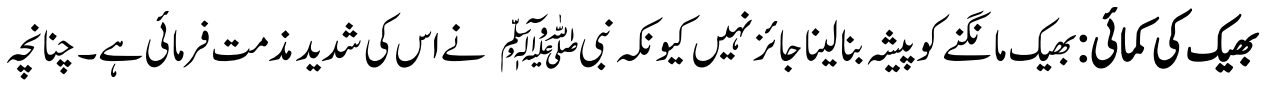

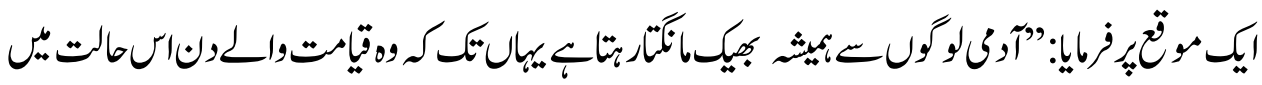

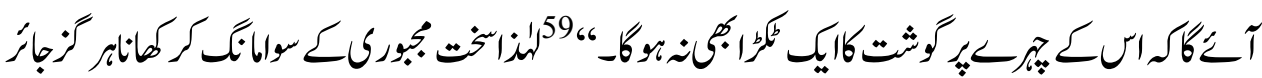

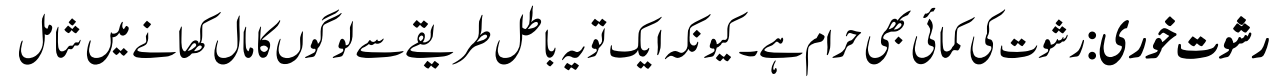

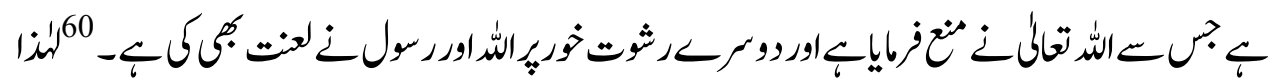

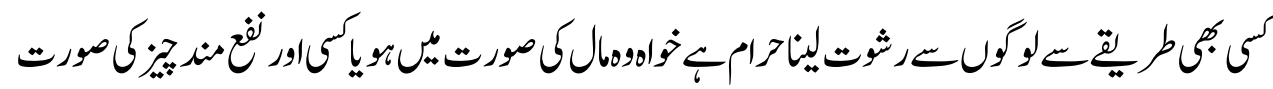

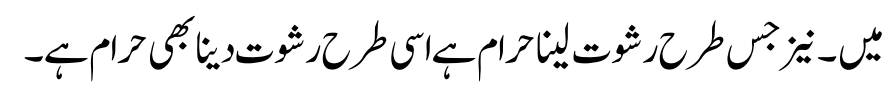

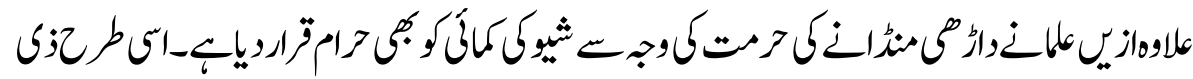

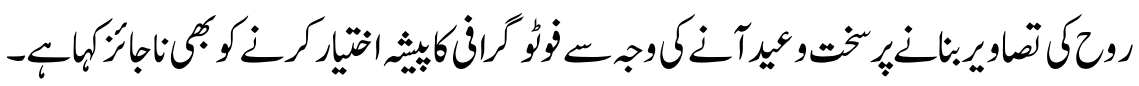

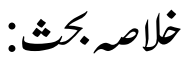

\footnotetext{
${ }^{57}$ Sunan Abī Dāwūd, Hadīth: 3904.

${ }^{58}$ Șahịh al-Bukhārī , Hadīith \#3842

${ }^{59}$ Ṣahịḥ̣ al-Bukhārī , Hadīth \#1484.

${ }^{60}$ Sunan Ibn Mājah, Hadīith \#3580., Sunan Abī Dāwūd, Hadīth: 3580.
} 


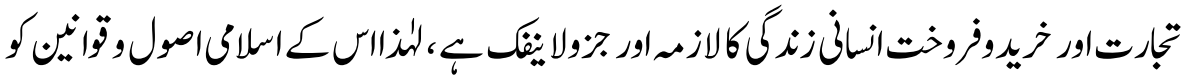

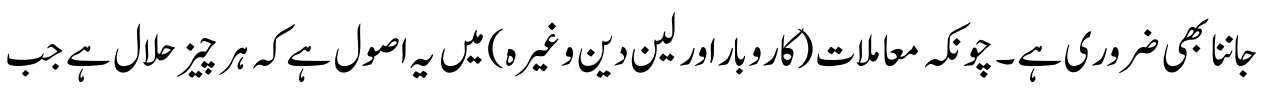

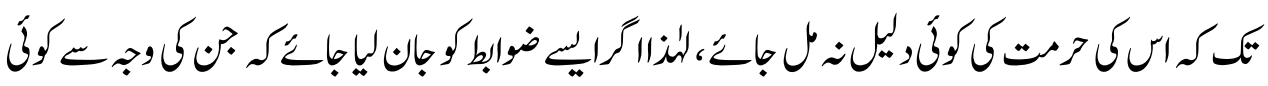

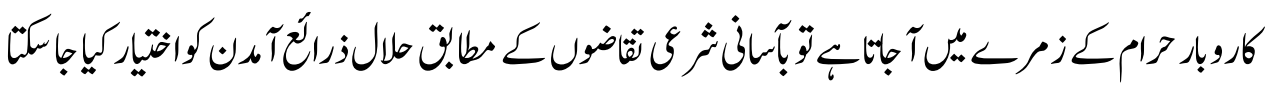

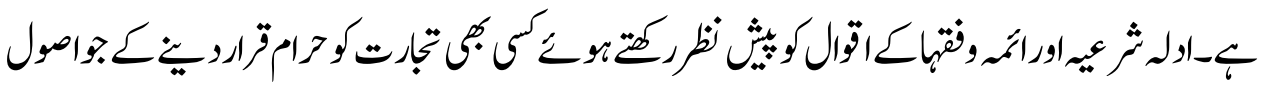

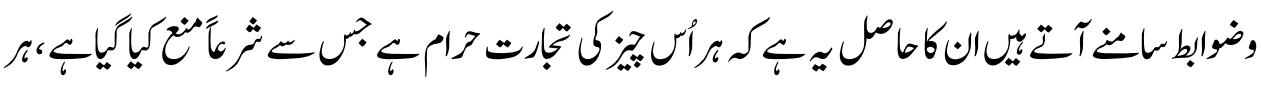

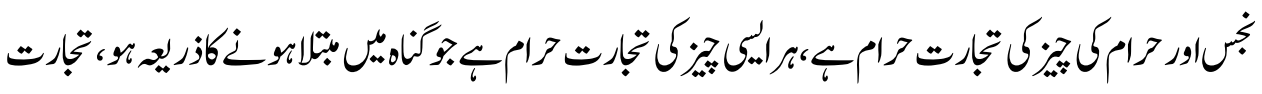

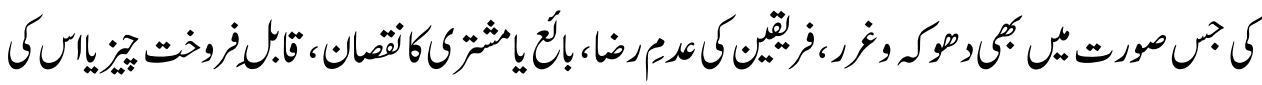

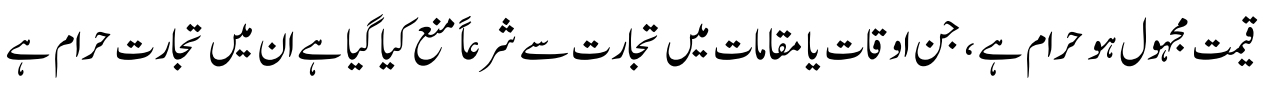

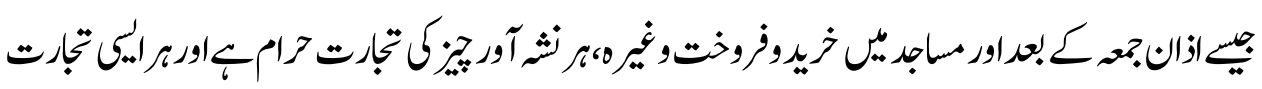

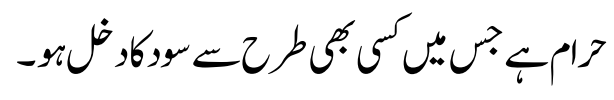

\section{(C)(1)(}

BY NC SA This work is licensed under a Creative Commons Attribution-NonCommercial-ShareAlike 4.0 International (CC BY-NC-SA 4.0) 